\title{
Targeted therapies for advanced non-small cell lung cancer
}

\author{
Xiaojuan Ai ${ }^{1}$, Xialing Guo ${ }^{2}$, Jun Wang ${ }^{1}$, Andreea L. Stancu ${ }^{3}$, Patrick M.N. Joslin ${ }^{4}$, \\ Dianzheng Zhang ${ }^{5}$ and Shudong Zhu $\mathbf{u}^{1,2}$ \\ ${ }^{1}$ National Key Discipline of Genetics, School of Life Sciences, Central South University, Changsha, China \\ ${ }^{2}$ Argus Pharmaceuticals, Changsha, China \\ ${ }^{3}$ Department of Dermatology, Brigham and Women's Hospital, Harvard Medical School, Boston, MA, USA \\ ${ }^{4}$ Division of Hematology/Oncology, Beth Israel Deaconess Medical Center, Harvard Medical School, Boston, MA, USA \\ ${ }^{5}$ Department of Bio-Medical Sciences, Philadelphia College of Osteopathic Medicine, Philadelphia, PA, USA \\ Correspondence to: Shudong Zhu, email: shudongzhu@csu.edu.cn \\ Keywords: NSCLC; molecular target; mTOR; EGFR; PI3K
}

Received: August 23, $2017 \quad$ Accepted: February 24, $2018 \quad$ Published: December 25, 2018

Copyright: Ai et al. This is an open-access article distributed under the terms of the Creative Commons Attribution License 3.0 (CC BY 3.0), which permits unrestricted use, distribution, and reproduction in any medium, provided the original author and source are credited.

\section{ABSTRACT}

Lung cancer is a serious health problem and the leading cause of cancer death worldwide, due to its high incidence and mortality. $85 \%$ of lung cancers are represented by the non-small cell lung cancer (NSCLC). Traditional chemotherapy has been the main treatment option in NSCLC. However, it is often associated with limited efficacy and overall poor patient survival. In recent years, molecular targeting has achieved great progress in therapeutic treatment of cancer and plays a crucial role in the current clinical treatment of NSCLC, due to enhanced efficacy on cancer tissues and reduced toxicity for normal tissues. In this review, we summarize the current targeting treatment of NSCLC, including inhibition of the epidermal growth factor receptor (EGFR), phosphatidylinositol 3-kinase (PI3Ks), mechanistic target of rapamycin (mTOR), epidermal growth factor receptor 2 (ErbB2), vascular epidermal growth factor receptor (VEGFR), kirsten human rat sarcoma protein (KRAS), mesenchymalepithelial transition factor or hepatocyte growth factor receptor (C-MET), anaplastic lymphoma kinase (ALK), v-Raf murine sarcoma viral oncogene homolog B (BRAF). This article may serve as a guide to clinicians and researchers alike by assisting in making therapeutic decisions. Challenges of acquired drug resistance targeted therapy and imminent newer treatment modalities against NSCLC are also discussed.

\section{INTRODUCTION}

Latest reports showed that lung cancer remains the most common fatal malignancy among males in the world [1]. Approximately $80 \%$ of cases are non-small cell lung cancer (NSCLC), and majority of NSCLC patients present with symptoms in a late advanced stage [2]. Despite recent advances in chemotherapy, the outcome for individuals with NSCLC is extremely poor. Generally, 5 -year survival rate for lung cancer does not exceed $15 \%$

PFS (Progression-free Survival): the length of time during and after the treatment of a disease, such as cancer, that a patient lives with the disease but it does not get worse OS (Overall Survival): the time from randomization to the date of death or the date of termination of the trial (for patients alive at the time end of the study), or the date of the last follow-up information available (for patients loss before the trial end date) ORR (Objective Response Rate): the number of complete plus partial response divided by the total of patients enrolled in each comparison arm. 
[3]. Thus, novel treatment strategies based on targeted therapy and targeted compounds started to be developed and implemented by researchers and clinicians. Up to now, several anti-cancer drugs targeting epidermal growth factor receptor (EGFR), phosphatidylinositol 3-kinase (PI3Ks), mechanistic target of rapamycin (mTOR), epidermal growth factor receptor 2 (ErbB2), vascular epidermal growth factor receptor (VEGFR), kirsten human rat sarcoma protein (KRAS), mesenchymal-epithelial transition factor or hepatocyte growth factor receptor (c-MET), anaplastic lymphoma kinase (ALK), v-Raf murine sarcoma viral oncogene homolog B (BRAF) have been developed, with undergoing clinical trials (Figure 1). Genetic changes of other genes have been identified (Figure 2), but EGFR, ALK and KRAS mutations are the most frequent mutations in lung cancer. To some extent, most of these inhibitors have shown promising anti-tumor efficacy, causing a paradigm shift for the treatment of advanced NSCLC, although some serious side effects, such as nausea, vomiting, hair loss and fatigue have been found in clinical trials [4-6]. In this review, we outline the recent progresses along with the emerging obstacles in NSCLC therapy.

\section{CHEMOTHERAPY}

\section{Cisplatin}

Cisplatin, as a non-specific drug working on cell cycle, is one of the common chemotherapeutic drugs in clinic, and acts as an anti-tumor drug mainly through suppressing DNA replication [7]. Additionally, cisplatin has anticancer activity by damaging the cellular membrane [8]. In advanced NSCLC, patients receiving cisplatinbased chemotherapy had shown significantly improved survival and quality of life along with many side-effects [9-11]. In a multinational, multicenter, open-label, phase III trial, 1125 patients with advanced NSCLC were randomly assigned to receive cisplatin alone and cisplatin plus cetuximab (an EGFR tyrosine kinase inhibitor). The results showed that patients survived longer in cisplatin plus cetuximab group than those in the cisplatin-alone

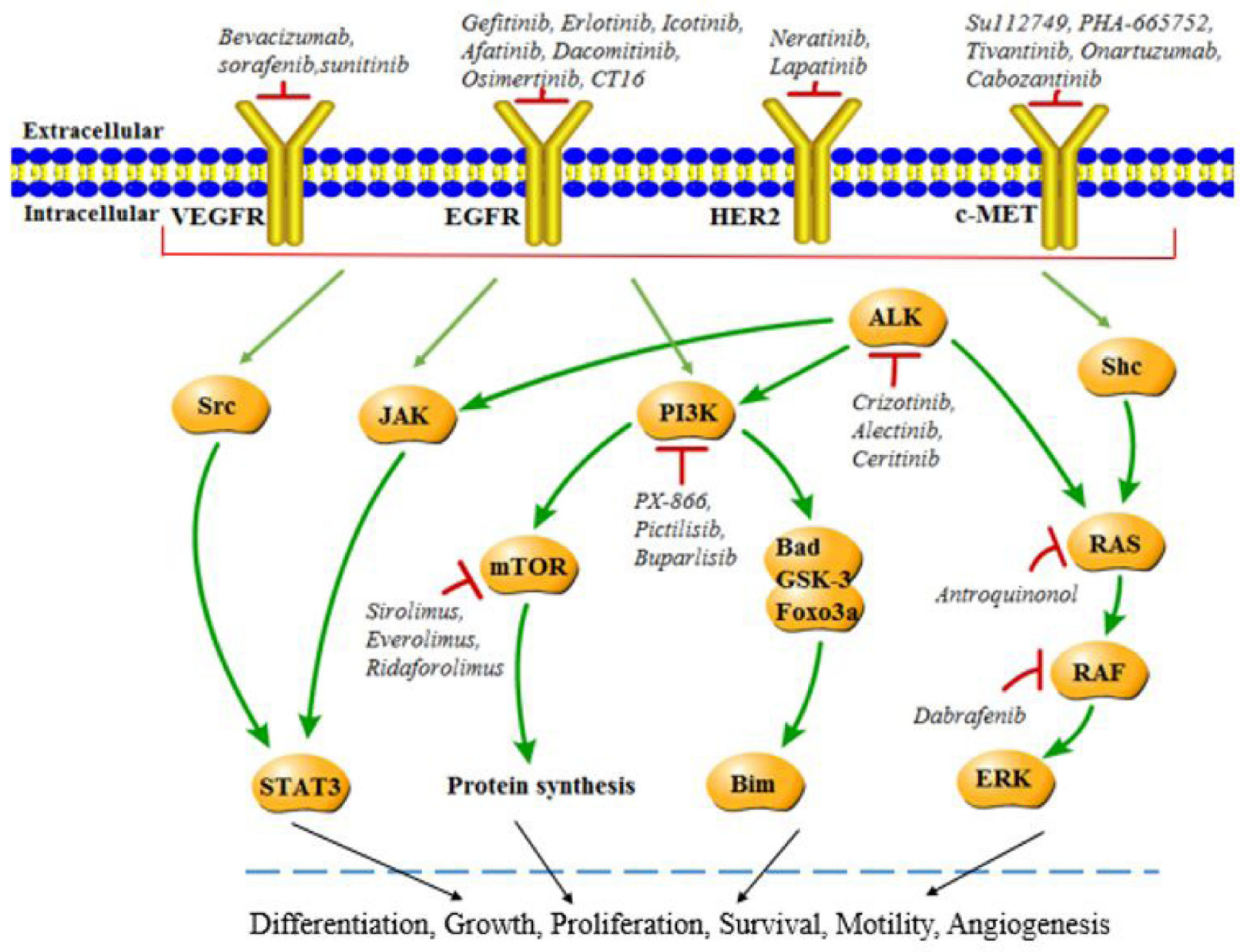

Figure 1: Molecular targets in NSCLC. Various mechanisms including amplification and mutation may lead to activation of EGFR, PI3K, mTOR, HER2, KRAS, c-MET, ALK, BRAF and corresponding signaling pathways, while targeting inhibitors suppress the activation in NSCLC and result in therapeutic effects. 
group (median survival is 11.3 months versus 10.1 months; hazard ratio (HR) for death: $0.87, p=0.04$ ). Grade 3 or 4 side effects (acne-like rash:10\%; diarrhea: $5 \%$; infusion-related: $4 \%$ ) were seen more in cisplatin plus cetuximab group [12]. In another phase II study, 39 patients with advanced NSCLC were randomly assigned to receive pemetrexed (a DNA/RNA synthesis inhibitor)cisplatin $\left(500 \mathrm{mg} / \mathrm{m}^{2}\right.$, intravenously) concurrent with radiotherapy. The progression free survival (PFS) was 11.8 months, median overall survival (OS) was 30.3 months and time to progressive disease was 13.7 months. The response rate was approximately $46.0 \%$. Grade 3 to 4 side effects (hematologic and esophagitis) were observed in this study [13]. These observations suggest that although cisplatin and cisplatin-based combinations have significant anticancer effects in NSCLC treatment, many side effects are also observed in the same time.

\section{Paclitaxel}

Paclitaxel, a novel anti-microtubule drug, functions as anti-cancer reagent through maintaining tubulin stabilization and inhibiting cell mitosis. Although the clinical study showed paclitaxel's effect on ovarian cancers and breast cancers $[14,15]$, it has certain curative effect on lung cancer, colorectal cancer, melanoma, head and neck cancer, lymphoma, brain tumors as well [16]. In a phase $\amalg$ trail, 134 patients with advanced NSCLC were randomly assigned to two groups: paclitaxel at $15 \mathrm{mg} / \mathrm{m}^{2}$ (three times/week for 6 weeks, $n=74$ ) and paclitaxel at $45 \mathrm{mg} / \mathrm{m}^{2}$ (weekly for 6 weeks, $n=60$ ). Interestingly, the response rate for low-dose paclitaxel was significantly higher than high-dose paclitaxel $(83.1 \%$ vs $54.2 \%$, $p=0.001$ ). Recurrence-free survival (RFS) in lowdose paclitaxel group was also superior than in highdose paclitaxel group (14.6 months vs 9.4 months,
$\mathrm{HR}=1.87,95 \% \mathrm{CI}$ (confidence interval) $=1.20-2.90$, $p=0.005$ ). Serious toxicities including grade 3 and 4 leukopenia/neutropenia were less occurred in lowdose paclitaxel group $(p<0.001)$ [17]. Nevertheless, a large number of side effects, such as allergic reactions, myelosuppression, neurotoxicity, cardiovascular toxicity and gastrointestinal reactions, were observed in these paclitaxel clinical trials [18-20]. Herein, a growing number of clinical trials are now investigating if nanoparticle paclitaxel could be a better treatment option as an anti-NSCLC therapy, with lower side effects. In a randomized and placebo-controlled clinical study, 92 patients with advanced NSCLC, after first-line platinum based chemotherapy failure, were randomly assigned to receive nanoparticle albumin-bound paclitaxel (nab-paclitaxel) or placebo. The median PFS was longer in nab-paclitaxel than in placebo (4.6 months vs 2.0 months; $\mathrm{HR}=0.62,95 \% \mathrm{CI}=0.33-0.81$, $p<0.001)$. The median OS was 6.3 months versus 4.9 months in nab-paclitaxel and placebo, respectively $(\mathrm{HR}=0.71 ; 95 \% \mathrm{CI}=0.33-0.85, p<0.001)$. However, adverse events were also observed in nab-paclitaxel [21]. Similar to cisplatin and paclitaxel, nab-paclitaxel has anti-tumor efficacy with serious side effects [21].

\section{TARGETED SMALL-MOLECULE INHIBITORS}

\section{EGFR mutation and EGFR tyrosine kinase inhibitors}

\section{EGFR mutation}

Epidermal Growth Factor Receptor (EGFR, HER1) belongs to a family of ErbB receptors that includes ErbB-1, ErbB-2, ErbB-3 and ErbB-4, and is critical

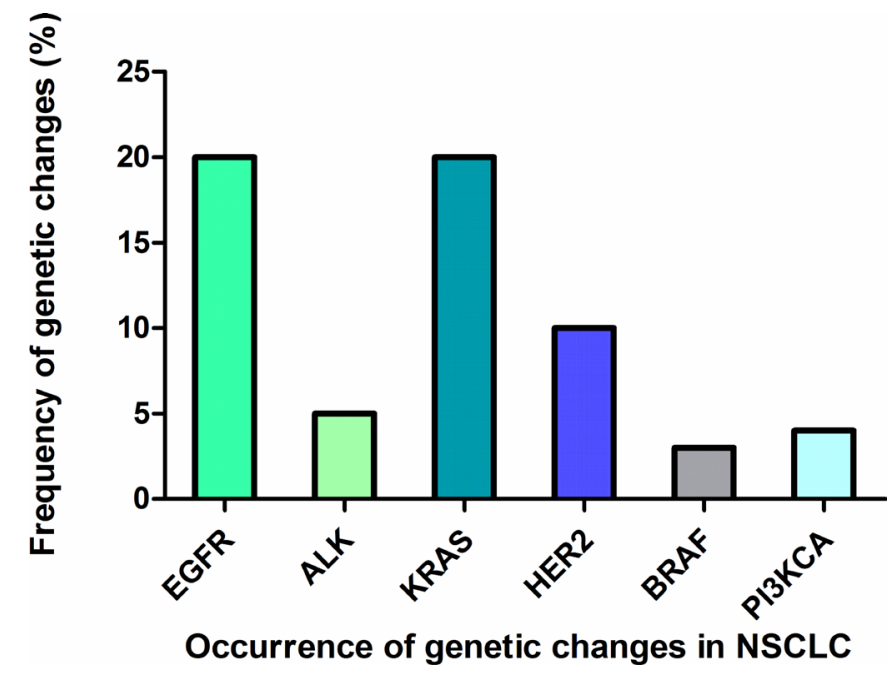

Figure 2: Occurrence of genetic changes in NSCLC. The frequency of different genetic changes occurred in NSCLC including EGFR, ALK, KRAS, HER2, BRAF, PI3KCA. 
for tumor development, metabolic and physiological processes [22]. EGFR mutations are most prevalent and well characterized in NSCLC [23]. Numerous studies have reported that EGFR mutations frequently occurred especially in substitution of arginine for leucine at amino acid position 858 (L858R) within exon 21, and an inframe deletion within exon 19 (delE746-A750) in NSCLC patients, which accounts for $85 \%$ of EGFR mutations [24-26]. NSCLC patients harboring EGFR ${ }^{\mathrm{L} 858 \mathrm{R}}$ mutation have benefited from EGFR TKIs treatments [27-30]. However, most NSCLC patients initially responding to gefitinib and erlotinib eventually become resistance [31]. In some cases, the drug resistance is a result of a second point mutation in the TK domain, in which the point mutation threonine-to-methionine substitution at position 790 (T790M) occurs in approximately one half of these acquired resistance cases [32].

\section{EGFR-TKI}

\section{Gefitinib}

Gefitinib, the first generation of EGFR TKIs, was approved by Food and Drug Administration (FDA) in 2003 as the second line drug for the treatment of patients with advanced NSCLC after failure of both platinumbased and docetaxel therapies [33]. It has been newly approved by FDA as the first-line treatment of patients with metastatic NSCLC bearing EGFR exon 19 deletions or exon 21 (L858R) mutations in 2015 [33]. The post-hoc analyses of the phase III, randomized, multicenter, Iressa Pan-ASia Study (IPASS) study of 261 Asian patients (nonsmokers) with EGFR mutation-positive advanced NSCLC were randomly assigned to receive gefitinib (250 mg/day) versus carboplatin/paclitaxel [34]. The median PFS suggested a statistically significant improvement with gefitinib (10.9 months) versus carboplatin/paclitaxel (7.4 months; $\mathrm{HR}=0.54,95 \% \mathrm{CI}=0.38-0.79, p=0.0012$ ). The objective response rate (ORR) was significantly higher with gefitinib $(67.0 \%)$ than with carboplatin/ paclitaxel (40.8\%) $(\mathrm{OR}=3.00 ; 95 \% \mathrm{CI}=1.63-5.54$; $p<0.001)$. The median disease progression (DoR) was 9.6 months $(95 \% \mathrm{CI}=7.4-12.5)$ and 5.5 months $(95 \% \mathrm{CI}=4.1-5.7)$ in the gefitinib group and carboplatin/ paclitaxel group, respectively. Nevertheless, vomiting, nausea, diarrhea and interstitial lung disease have been observed in gefitinib group [34]. EGFR inhibition and/or drug off-targets effects might cause these adverse events [35]. Thus, to minimize the side effects, identification the off-targets of gefitinib may be an important task. Recently, by the systems biology based on silico analysis, the crystal structure of EGFR-gefitinib complex was used to identify off-targets of gefitinib through binding pocket similarity searches on a druggable proteome database (Sc-PDB) [36]. Besides EGFR, mitogen activated protein kinase 10 (MAPK10), polymer of intrinsic microporosity-1 (PIM-1), dihydroorotate dehydrogenase (DHODH), epidermal growth factor receptor 4 (ERBB-4), $17 \beta$ Hydroxysteroid dehydrogenase type 1 (HSD17B1), checkpoint kinase-2 (CHK2) as well as checkpoint kinase-1 (CHK1) also efficiently binds gefitinib [36]. Although gefitinib has shown high efficacy in patients with advanced NSCLC, drug resistance is commonly acquired when associating with EGFR T790M. Gefitinib in combination with AT101 (a pan-Bcl-2 inhibitor) significantly inhibits cell proliferation, as well as promotes apoptosis of NSCLC cells involving blocking of B-cell lymphoma-2 (Bcl-2), B-cell lymphoma-xl (Bcl-xl), and myeloid cell leukemia-1 (Mcl-1) and downregulating of EGFR signaling [37, 38]. Animal studies further supported that the combination of gefitinib with AT-101 reinforces efficacy in NSCLC with EGFR T790M mutations [38].

\section{Erlotinib}

Erlotinib is another first-generation TKI that reversibly binds to EGFR approved by FDA in 2004. In 2013, it was approved by FDA as the first-line treatment for patients with metastatic NSCLC harboring EGFR exon 19 deletions or exon 21 (L858R) mutations [39]. In an open-label, randomized, multicenter, phase II study, 154 patients with advanced NSCLC with activating EGFR mutations randomly received erlotinib (150 mg/day) monotherapy or erlotinib (150 mg/day) plus bevacizumab $(150 \mathrm{mg} / \mathrm{kg})$ as a first-line therapy. The median PFS was 16.0 months in the erlotinib plus bevacizumab group (95\% CI $=13.9-18.1)$ and 9.7 months in the erlotinib alone group $(\mathrm{HR}=0.54,95 \% \mathrm{CI}=0.36-0.79, p=0.0015)$ [40]. The most common grade 3 or worse adverse events were occurred with higher frequently in the erlotinib plus bevacizumab group than erlotinib alone group (25\% vs $19 \%)$. Frequency of serious adverse events (24\% vs $25 \%$ ) in both groups was similar [40].

\section{Icotinib}

Icotinib, an oral selective EGFR TKI, has been approved by the China Food and Drug Administration (CFDA). In a phase III non-inferiority trial in 27 hospitals in China, 400 advanced NSCLC patients not responding to platinum-based chemotherapy were treated with either gefitinib $(250 \mathrm{mg} /$ day $)$ or icotinib $(125 \mathrm{mg} / \mathrm{tid})$. The median PFS was 4.6 months versus 3.4 months in icotinib group and gefitinib group, respectively $(\mathrm{HR}=0.8,95 \% \mathrm{CI}=0.7-1.1, p=0.13)$, indicating that icotinib was non-inferior to gefitinib [41]. Drug-related adverse events, especially drug-related diarrhea (19\% vs $28 \%, p=0.033$ ), were less occurring in icotinib group, compared with patients receiving gefitinib (61\% vs $70 \%$, $p=0.046$ ) [41]. Another study has also demonstrated higher efficacy and safety with icotinib for patients with advanced NSCLC after chemotherapy treatment. In this single-arm, multi-center, prospective study, 128 NSCLC patients after chemotherapy treatment were randomly 
selected to receive icotinib (375 $\mathrm{mg} /$ day). The median PFS was 5.0 months $(95 \% \mathrm{CI}=2.9-6.6)$ and time to progression was 5.4 months $(95 \% \mathrm{CI}=3.1-7.9)$. The disease control rate and ORR were $67.7 \%$ and $25.8 \%$, respectively. Rash (26\%), diarrhea $(12.6 \%)$ were seen in the icotinib treatment [42].

\section{Afatinib}

Afatinib is a second-generation EGFR TKI. It was approved by FDA in 2013 as a first-line treatment of patients with metastatic NSCLC bearing mutant EGFR (exon 19 deletions or exon 21 mutations) [43]. In randomized phase $\amalg$ trial based on 36 centers covering China, South Korea and Thailand, 910 Asian patients with advanced NSCLC were randomly assigned in three groups: afatinib (40 mg/day), gemcitabine $\left(1000 \mathrm{mg} / \mathrm{m}^{2}\right)$ and cisplatin $\left(75 \mathrm{mg} / \mathrm{m}^{2}\right)$. There was a significantly longer median PFS in afatinib group (11 months, 95\% $\mathrm{CI}=9.7-13.7)$ than that in either gemcitabine group or cisplatin group [44]. In another phase III study, 345 patients with stage IIIB/IV lung adenocarcinoma of EGFR mutations (exon 19 deletion, L858R, or other) were randomly assigned to either afatinib (40 mg/day) or cisplatin plus pemetrexed. It was found that the median PFS of afatinib-treated patients harboring exon 19 deletions and EGFR ${ }^{L 858 R}$ mutation was 13.6 months, much longer than the median PFS of cisplatin plus pemetrexed group (6.9 months, $\mathrm{HR}=0.47,95 \% \mathrm{CI}=0.34-0.65, p=0.001$ ) [45]. Diarrhea, rash/acne, and stomatitis were observed in afatinib, while nausea, fatigue, and decreased appetite were occurred in chemotherapy [45]. Additionally, afatinib as an effective first-line treatment drug has presented definite good results in advanced NSCLC patients with EGFR-mutations who had received erlotinib, gefitinib, or both before [46-48].

\section{Dacomitinib}

Dacomitinib is a second-generation, irreversible TKI of EGFR that shows efficacy in NSCLC patients both in initial treatment and after failing treatment of firstgeneration inhibitors. The superiority of dacomitinib to its first generation TKI counterparts in advanced NSCLC was further characterized in a phase II trial: 66 patients with advanced NSCLC after failure of prior chemotherapy and erlotinib were randomly assigned to dacomitinib (45 mg/day). The median PFS was 12 weeks overall $(n=66)$ and 18 weeks $(n=26)$ for patients with EGFR mutation-positive tumors. Diarrhea, acneiform dermatitis, exfoliative rash, fatigue and stomatitis were observed in dacomitinib treatment. The results showed dacomitinib is preliminary activity and acceptable tolerability in heavily pretreated patients [49]. Clinical data showed dacomitinib has significant efficacy in advanced NSCLC patients with EGFR exon 19 deletion [50]. In the pooled subset analyses, two clinical trials were used to test the efficacy of dacomitinib in NSCLC. The ARCHER 1009 (NCT01360554) and A7471028 (NCT00769067) studies randomly assigned advanced NSCLC patients to either dacomitinib or erlotinib, while EGFR alteration examination was performed centrally on archived tumor samples. The median PFS was 14.6 months with dacomitinib and 9.6 months with erlotinib $(\mathrm{HR}=0.717$, $95 \% \mathrm{CI}=0.458-1.124 ; p=0.146)$. The median survival was 26.6 months with dacomitinib versus 23.2 months with erlotinib $(\mathrm{HR}=0.737,95 \% \mathrm{CI}=0.43-1.259$, $p=0.265$ ) [50]. The results showed that dacomitinib has similar or better efficacy to erlotinib in patients with EGFR mutations. Interestingly, individuals with exon 19 deletion have more favorable outcomes with dacomitinib than with erlotinib.

\section{Osimertinib (AZD9291)}

Osimertinib is a third-generation TKI that binds to EGFR and was approved by FDA in 2015 for patients with metastatic $E G F R^{T 790 M}$ NSCLC progressing on or after EGFR TKI therapy. NSCLC patients harboring an EGFRactivating mutation develop acquired resistance after a median of 9-11 months from the beginning of treatment with TKI, such as erlotinib and gefitinib [51, 52]. Osimertinib is a highly selective EGFR mutant inhibitor, which has been developed to be potent against EGFR mutations, including T790M mutation, while sparing wild-type EGFR $[53,54]$. Dr. Jänne showed that in a group of 253 lung cancer patients with or without $E G F R^{T 790 M}$ mutation receiving osimertinib at a dose of 20-240 mg/day, the median PFS is much longer in EGFR T790M-positive patients than in EGFR T790M-negative patients (9.6 months vs 2.8 months), suggesting that advanced NSCLC patients with the $E G F R^{T 790 M}$ mutation were extraordinary sensitive to osimertinib (95\% CI $=8.3$-not reached) [55]. Different technology platforms have been used to assess the sensitivity and specificity of osimertinib to patients with $E G F R^{T 790 M}$ mutation. Results showed that patients with $E G F R^{T 790 M}$ mutation possess high sensitivity and specificity to osimertinib [56]. All observations suggest that patients with T790M mutation or resistance to EGFR TKI could be benefited from osimertinib.

\section{CT16}

CT16, targeting both EGFR and Notch2/3 receptors, not only inhibited signaling mediated by these receptors, but also showed a strong anti-stem cell effect both in vitro and in vivo. Data showed CT16 limits acquiring resistance to EGFR inhibitors and radiation in NSCLC cell line and patient-derived xenograft tumors. On the other hand, CT16 had a superior radio-sensitizing impact than other EGFR inhibitors [57]. These findings suggest that CT16 combining radiation may reveal clinical efficacy for patients with NSCLC. 


\section{PI3KCA mutation and PI3Ks inhibitors}

\section{PI3KCA mutation}

Phosphatidylinositol 3-kinases (PI3Ks) closely associates with cell proliferation, survival, adhesion and neoplasia [58]. The mutation of phosphatidylinositol 3-kinases catalytic alpha (PIK3CA) gene may play a role as an oncogene in human cancers [59], frequently occurring at exons 9 and 20 [60]. Mutant PIK3CA was found in approximately $4 \%$ NSCLC $[60,61]$.

\section{PI3Ks inhibitors}

\section{PX-866}

PX-866 is an irreversible, pan-isoform inhibitor of PI3Ks. Nathan et al. have shown that PX-866 improved the antitumor activity of gefitinib in A549 NSCLC xenografts [62]. However, the main results were divergent in a randomized, phase II trial: 95 patients with advanced, recurrent, or metastatic NSCLC randomly assigned to docetaxel $\left(75 \mathrm{mg} / \mathrm{m}^{2}\right.$, intravenous) with (group A, $8 \mathrm{mg} /$ day, orally) or without PX-866 (group B). The median PFS was 2 months in group A and 2.9 months in group $\mathrm{B}(p=0.65)$; the ORR was $6 \%$ and $0 \%$ in group A and group $\mathrm{B}$, respectively $(p=0.4)$. There was no difference in OS between the two groups (7.0 months vs 9.2 months, $p=0.9$ ) [63]. Diarrhea (7\%), vomiting (7\%) and nausea (4\%) occurred more in group A, with less number of grade 3 or higher adverse events found in both two groups [63]. The observations suggest that the efficacy of PX-866 is dependent on the treatment strategies for NSCLC.

\section{Pictilisib (GDC-0941)}

Pictilisib is an oral class I PI3Ks inhibitor that is being evaluated in phase II clinical trials for the treatment of breast and NSCLC [64]. Pictilisib has shown good safety and tolerability for NSCLC in the phase Ia/Ib study: Japanese patients with non-squamous NSCLC or advanced solid tumors received pictilisib in monotherapy (group A) or in combination with carboplatin-paclitaxel and bevacizumab (group B). The dose escalation of pictilisib was designed in this study for two stages: 140 , 260 , or $340 \mathrm{mg}$ /day of pictilisib was administrated as monotherapy (stage 1) and 260 or $340 \mathrm{mg} /$ day of pictilisib plus chemotherapy and bevacizumab was administrated (stage 2). In stage 1, only grade 3 maculopapular rash was found at the dose of $340 \mathrm{mg} /$ day in group A, while an objective anti-tumor response was not observed. In stage 2 , only grade 3 febrile neutropenia occurred at the dose of $260 \mathrm{mg} /$ day or $340 \mathrm{mg} /$ day in group B, while partial anti-tumor responses were observed in 3 out of 7 patients [65]. The efficacy of pictilisib for NSCLC is yet to be established in clinical trials.

\section{Buparlisib (BKM120)}

Buparlisib is a pan-PI3Ks inhibitor. Buparlisib mediated cell growth arrest and apoptosis of NSCLC through down-regulating the expression of Mcl-1 [66]. It has also been reported that buparlisib up-regulated the levels of auto phagosome-bound type II LC3 (LC3-II) protein, contributing to autophagy and disappearing of NSCLC [66]. However, in the phase II BASALT-1 study: 63 patients (30 squamous and 33 non-squamous) with activated PI3K pathway, metastatic, squamous or nonsquamous NSCLC, who failed previous antineoplastic therapies (chemotherapy for squamous or systemic antineoplastic for non-squamous) received buparlisib $(100 \mathrm{mg}$ /day) for 12 weeks. The PFS rate was only $23.3 \%$ $(95 \% \mathrm{CI}=9.9-42.3)$ and $20.0 \%(95 \% \mathrm{CI}=7.7-38.6)$ in the squamous and non-squamous groups, respectively [67], possibly due to overlapping signaling of treatments former and latter. Furthermore, both in vitro and in vivo studies show that buparlisib plus MEK162 (a MEK inhibitor) highly improve therapeutic efficacy against the growth of NSCLC cells [68]. Pre-clinical studies also showed that buparlisib combined with chloroquine inhibited lung cancer cells proliferation and induced apoptosis [69]. Combined therapies based on buparlisib hold promise for improving the clinical efficacy of patients with NSCLC.

\section{mTOR inhibitors}

Rapamycin binds two proteins (FK- 506 binding protein and FKBP-rapamycin-associated protein) as a potent immunosuppressive agent to inhibit mTORC1 [70]. Rapamycin has many derivatives including sirolimus, everolimus, ridaforolimus.

\section{Sirolimus}

Sirolimus is an oral mTOR inhibitor presenting unsatisfactory clinical efficacy. In a phase Ib trial, 39 NSCLC patients with EGFR mutation were randomly assigned to afatinib ( $40 \mathrm{mg} /$ day) plus sirolimus ( $5 \mathrm{mg} /$ day). The PFS was 6 months (33.3\%). Adverse events (diarrhea: $94.9 \%$, mucosal inflammation: $64.1 \%$, asthenia: $53.8 \%$ and rash: 53.8\%) were observed in all patients. Positive responses occurred in only 5 patients $(12.8 \%)$ [71]. The results showed the efficacy of afatinib ( $40 \mathrm{mg} /$ day) plus sirolimus was very much limited.

\section{Everolimus}

Everolimus is another novel inhibitor of mTOR pathway, yet demonstrating poor relatively clinical efficacy of combining with other drugs. In a phase II study, 28 patients with advanced stage NSCLC that previous had chemotherapy were treated with everolimus ( $5 \mathrm{mg} /$ day) and docetaxel $\left(60 \mathrm{mg} / \mathrm{m}^{2}\right)$. The partial response occurred 
in 2 patients and stable disease was found in 15 patients (clinical benefit rate, 70\%). The PFS was 6 months and OS was 9.6 months in everolimus plus docetaxel treatment. The results showed that everolimus plus docetaxel was tolerated well without satisfactory efficacy for patients with NSCLC [72]. Similarly, in another multicenter, openlabel, phase II study, 133 patients with advanced NSCLC that previous had chemotherapy were randomly assigned to everolimus (5 mg/day) plus erlotinib (150 mg/day) and erlotinib alone. The disease control rate (DCR) at 3 months in everolimus plus erlotinib group was $39.4 \%$ and in erlotinib alone group was $28.4 \%$. The median PFS was 2.9 months in everolimus plus erlotinib group and 2.0 months in erlotinib alone group. Grade 3/4 adverse events occurred in $72.7 \%$ and $32.3 \%$ of patients in everolimus plus erlotinib group and erlotinib alone group, respectively. Grade 3/4 stomatitis was only found in combination therapy (31.8\%) [73]. These observations overall suggest that, everolimus plus erlotinib in combination cannot be a novel treatment strategy for individuals with NSCLC.

\section{Ridaforolimus}

Ridaforolimus is an investigational oral inhibitor targeting mTOR pathway. Clinical data showed that ridaforolimus is a good choice for patients with advanced NSCLC. In a randomized discontinuation phase II trial, 28 stage IIIB/IV NSCLC patients with KRAS mutation were treatment with ridaforolimus ( $40 \mathrm{mg} /$ day) or placebo. The median PFS based on investigator assessment was obviously longer in ridaforolimus group (4 months) than placebo group ( 2 months, $\mathrm{HR}=0.36, p=0.013$ ). The median OS was 18 months and 5 months in the ridaforolimus and placebo group, respectively $(\mathrm{HR}=0.46$, $p=0.09$ ). More than 3 grade adverse events (fatigue: $10 \%$, mucositis/stomatitis: $10 \%$, pneumonia: $10 \%$, diarrhea: $6 \%$, dyspnea: $9 \%$, and hyperglycemia: $6 \%$ ) were observed in ridaforolimus group [74].

\section{ErbB2 amplification and ErbB2 inhibitors}

\section{ErbB2 amplification}

Human epidermal growth factor receptor 2 (ErbB2, HER2), a member of the human EGFR (ErbB) family, is a receptor tyrosine kinase and encoded by the HER2 gene located on the long arm of chromosome 17 (17q21). ErbB2 is involved in activation of its downstream signaling pathways including PI3K/Akt as well as MEK/ ERK, and necessary for cell proliferation and migration $[75,76]$. ErbB2 amplification is found in $10-20 \%$ of NSCLC, while ErbB2 protein over-expression is observed in $2.4-38 \%$ of NSCLC [77-79].

\section{ErbB2 inhibitors}

\section{Neratinib (HKI-272)}

Neratinib is an oral, irreversible dual EGFR/HER2 inhibitor. In vitro, neratinib could inhibit proliferation by inducing G1 arrest and apoptotic of lung cancer cells $[80,81]$. However, clinical data showed that the efficacy of neratinib for NSCLC was poor and low efficacy of neratinib for NSCLC patients had been observed in a phase II trial: NSCLC patients were assigned to group A (EGFR mutation, $n=91$ ), group B (wild-type EGFR, $n=48$ ), and group C (TKI-naïve, $n=28$ ). All of these patients were received neratinib daily. The ORR was $3 \%$ in group $\mathrm{A}$ and zero in both groups $\mathrm{B}$ and $\mathrm{C}$. The most common toxicity was diarrhea. Obviously, 3 of 4 patients with $E G F R^{G 719 X}$ mutation had a partial response [82]. Another phase I study also reported that neratinib plus temsirolimus treatment for NSCLC is associated with poor efficacy with side effects (diarrhea, nausea and stomatitis) [83]. Generally, further study will be needed for neratinib.

\section{Lapatinib (GW572016)}

Lapatinib is an oral, reversible, dual tyrosine kinase inhibitor of EGFR and HER2. The clinical efficacy of lapatinib monotherapy is uncertainty for NSCLC. In a randomized phase II study, patients with relapse or metastatic NSCLC were treated with lapatinib $(1,500 \mathrm{mg} /$ day or $500 \mathrm{mg} / \mathrm{bid}$, orally). There were no complete or partial responses in the targeted population $(n=56): 25 \%$ had stable disease lasting 6 months. No responses were observed in patients with EGFR mutations $(n=3)$ and EGFR gene amplification $(n=5) .21 \%$ had stable disease lasting 6 months and $1.3 \%$ had partial response of patients in the nontargeted population $(n=$ 75). Diarrhea, rash, fatigue, nausea, and anorexia were the most common adverse events [84]. The combination of lapatinib with other agents for treatment of NSCLC patients may be tested to improve the efficacy in the future.

\section{VEGFR inhibitors}

Vascular epidermal growth factor receptor (VEGFR) plays an important role in regulating of physiological angiogenesis that is closely associated with embryogenesis and tumor progress [85]. New blood vessel formation (angiogenesis) is required for the process of tumor growth and metastatic dissemination. Avascular tumors are severely restricted in their growth potential because of the lack of a blood supply [86]. Therefore, anti-angiogenesis is a valuable new approach to cancer therapy. 


\section{Bevacizumab}

Bevacizumab, a monoclonal antibody against vascular endothelial growth factor (VEGF), benefits patients with NSCLC. It was applied as the first-line treatment of locally advanced, recurrent, unrespectable, or metastatic NSCLC in combination with chemotherapy (carboplatin and paclitaxel) that was approved by FDA in 2006 [87]. In a prospective cohort study, 102 patients with non-squamous NSCLC (44.1\% of which carried EGFR mutation) received bevacizumab $(15 \mathrm{mg} / \mathrm{kg})$ with standard chemotherapy. The ORR was $44.1 \%$, and the median PFS was 8.3 months in bevacizumab with standard chemotherapy $(95 \% \mathrm{CI}=$ 6.4-10.2). The median OS was 26.3 months $(95 \% \mathrm{CI}=$ 22.2-30.4). Grade 3-4 hypertension (30.4\%) was observed in this study [88]. The results of this study showed that bevcontaining chemotherapy was effective and safe for patients with non-squamous NSCLC. In another pilot phase II study, 39 patients with advanced NSCLC were randomly assigned to treatment with paclitaxel $\left(80 \mathrm{mg} / \mathrm{m}^{2}\right)$ and gemcitabine $(300$ $\mathrm{mg} / \mathrm{m}^{2}$, weekly) for 3 weeks, plus bevacizumab $(10 \mathrm{mg} / \mathrm{kg}$, every two weekly). The median PFS was 8.5 months, the ORR was $56 \%$ and OS was 25.5 months. Myelosuppressive, gastrointestinal or neurologic events were not found in this study [89]. In addition, bevacizumab exhibited sufficient efficacy and safety for patients with NSCLC who failed firstline platinum-based chemotherapy: in a randomized phase III study, 297 Chinese patients were assigned to two groups: bevacizumab plus erlotinib and panitumumab (group A), or erlotinib plus placebo (group B). The median PFS in group A was much longer than in group B (4.6 months: $95 \% \mathrm{CI}=$ 2.3-9.4 vs 1.9 months: $95 \% \mathrm{CI}=0.8-5.2, p=0.003)$. The median OS was 10.4 months $(95 \% \mathrm{CI}=7.5-13.1)$ and 8.9 months $(95 \% \mathrm{CI}=3.3-10.9)$ in group A and group B ( $p=$ $0.031)$, respectively. Partial response in group A was $38 \%$, significantly higher than in group B $(15 \% ; p=0.014)$. In addition, diarrhea, fatigue and rash were occurred more in group B rather than group A [90]. These observations demonstrate that bevacizumab combination with other agents may have higher efficacy for patients with NSCLC.

\section{Sorafenib}

Sorafenib is an oral, multi-kinase inhibitor that was beneficent for NSCLC. In a multicenter phase II trial, 168 patients were randomly assigned to sorafenib (400 mg/day, bid) plus erlotinib (150 mg/day) or placebo plus erlotinib. The median PFS was 3.38 months and 1.94 months in sorafenib plus erlotinib and in placebo plus erlotinib, respectively $(\mathrm{HR}=0.86,95 \% \mathrm{CI}=0.60-1.22, p=0.196)$. The disease control rate was $54 \%$ in sorafenib plus erlotinib and $38 \%$ in placebo plus erlotinib $(p=0.056)$ [91]. Similar clinical efficacy has been showed in another single-arm and multicenter phase II trial: 53 patients with advanced NSCLC were assigned to sorafenib (800 $\mathrm{mg} /$ day). The median PFS and median OS were 2.7 months and 6.7 months, respectively [92]. These results indicate that sorafenib monotherapy or combination with other agents may be promising for NSCLC treatment.

\section{Sunitinib}

Sunitinib is an oral, multitargeted TKI targeting VEGFR, Kit, platelet-derived growth factor (PDGFR), FMS-like tyrosine kinase 3 (FLT3) and RET on tumor cells, tumor neovasculature and pericytes [93]. Clinical trials revealed that sunitinib had a certain extent efficacy to NSCLC with some side effects. In a phase III trial, 960 patients were randomly assigned to sunitinib (37.5 $\mathrm{mg}$ /day) plus erlotinib (150 mg/day) or placebo plus erlotinib. The median PFS was 3.6 months in sunitinib plus erlotinib versus 2.0 months in erlotinib alone (HR $=0.807 ; 95 \% \mathrm{CI}=0.695-0.937, p=0.0023)$, and ORR was $10.6 \%$ versus $6.9 \%$ in sunitinib plus erlotinib and in erlotinib alone $(p=0.0471)$, respectively. The median OS was 9.0 months and 8.5 months in sunitinib plus erlotinib and in erlotinib alone, respectively $(\mathrm{HR}=$ $0.922 ; 95 \% \mathrm{CI}=0.797-1.067, p=0.1388)$. However, $\mathrm{rash} /$ dermatitis, diarrhea and asthenia/fatigue were more frequently observed in the sunitinib plus erlotinib group [94]. The same situation happened in another randomized, double-blind, placebo-controlled phase III study: 210 patients with stage IIIB/IV NSCLC who experiencing first-line chemotherapy were randomized to receive sunitinib (37.5 $\mathrm{mg}$ /day) or placebo. The median PFS was 4.3 months in sunitinib and 2.6 months in placebo $(\mathrm{HR}=0.62,95 \% \mathrm{CI}=0.47-0.82, p$ $=0.0006)$. The median OS was 11.7 months in sunitinib versus 12.1 months in placebo $(\mathrm{HR}=0.98,95 \% \mathrm{CI}=$ $0.73-1.31, p=0.89)$. Serious effects including fatigue $(25 \%)$, thrombocytopenia $(12 \%)$, hypertension $(12 \%)$ and rash (11\%) were occurred in sunitinib [95]. These results indicate that sunitinib in combination or alone is beneficial for advanced NSCLC.

\section{KRAS mutation and KRAS inhibitors}

\section{KRAS mutation}

In NSCLC, and especially in lung adenocarcinomas, signaling of kirsten human rat sarcoma protein (KRAS), a main downstream signaling molecule of EGFR pathway, is frequently influenced by its own somatic mutations $[96,97]$. Mutations of EGFR and KRAS are regarded as primary genetic "driver" leading to cancer [98]. KRAS is frequently activated in NSCLC, and KRAS gene mutations were found in $20 \%$ of NSCLC. Most KRAS mutations reported in NSCLC were found at codon 12 [97]. Although KRAS mutations were identified in lung cancer, there have been very few trials addressing NSCLC patients with KRAS mutations, leading to no positive therapies [99]. However, there is a dire need for therapies specifically for patients with KRAS mutant NSCLC. 


\section{KRAS inhibitor}

\section{Antroquinonol}

Antroquinonol is a small anticancer molecule isolated from Antrodia camphorate which shows highly anticancer activity [100, 101]. Antroquinonol inhibited Ras and Ras-related small GTP-binding protein functions by binding directly to farnesyltransferase and geranylgeranyl transferase-I (the key enzymes associated with activation of Ras-related proteins). Furthermore, antroquinonol induced autophagy by increasing the level of light chain 3 B- II (LC3B-II) and the auto phagosome-associated LC3 [102]. In an open-label, dose escalation, pharmacokinetic (PK) study, 13 patients with metastatic adenocarcinoma NSCLC were treated with antroquinonol (escalating doses of 50-600 mg/day). No dose-limiting toxicities was seen in any patient at any dose level. The mean elimination half-life is between 1.30 and $4.33 \mathrm{~h}$, which associates with the treatment dose. A mild toxicity profile was observed at all dose levels of antroquinonol. Diarrhea, vomiting and nausea occurred in this study. The best tumor response was stable disease in 3 patients [103]. This study showed that antroquinonol was good, safe and tolerated for NSCLC. The efficacy of antroquinonol in clinical trials have still to be evaluated.

\section{c-MET amplification and c-MET inhibitors}

\section{c-MET amplification}

Cellular-mesenchymal to epithelial transition factor (c-MET) is a plasma membrane tyrosine kinase activated by auto-phosphorylation after ligand binding. The c-MET was significantly associated with tumor growth in NSCLC [104]. Additionally, a recent study has shown that MET amplifications are present in 9 of 43 patients with acquired resistance to EGFR TKI (gefitinib and erlotinib) [105]. MET amplification was also observed in 4 of 18 lung cancer patients with gefitinib or erlotinib-resistance [106]. These data suggest that MET amplification may play an important role in promoting drug resistance. The c-MET receptor is an attractive potential target for novel therapeutic inhibition in human cancers.

\section{c-MET inhibitors}

\section{Tivantinib}

Tivantinib, an oral MET receptor TKI, exhibited high anticancer activity in early clinical studies and preclinical studies when combined with erlotinib. In a phase III multinational, randomized, double-blind, placebo-controlled study, 1,048 patients with advanced non-squamous NSCLC were randomly assigned to receive erlotinib (150 mg/day) plus tivantinib $(720 \mathrm{mg} /$ day $)$ or erlotinib plus placebo. The median PFS was 3.6 months in erlotinib plus tivantinib and 1.9 months in erlotinib alone $(\mathrm{HR}=0.74,95 \% \mathrm{CI}=0.62-0.89, p<0.001)$. The median OS was 8.5 months versus 7.8 months in erlotinib plus tivantinib and in erlotinib alone, respectively $(\mathrm{HR}=0.98$, $95 \% \mathrm{CI}=0.84-1.15, p=0.81)$. Diarrhea (34.6\% vs $41.0 \%$ ), rash $(33.1 \%$ vs $37.3 \%$ ), neutropenia (grade 3 to $4 ; 8.5 \%$ vs $0.8 \%)$ and asthenia or fatigue (43.5\% vs $38.1 \%$ ) were seen in both erlotinib plus tivantinib and in erlotinib group [107].

\section{Onartuzumab (MP470)}

Onartuzumab is a monovalent monoclonal antibody targeting MET. Clinical data showed that onartuzumab is a good choice for MET-positive patients with NSCLC. In a randomized phase II trial, patients with recurrent NSCLC were randomly assigned to receive onartuzumab plus erlotinib or placebo plus erlotinib [108]. No definite conclusion has been derived in PFS (2.2 months vs 2.6 months; $\mathrm{HR}=1.09, p=0.69)$ or OS (8.9 months vs 7.4 months; $\mathrm{HR}=0.80, p=0.34$ ) in the intent-totreat (ITT) population $(n=137)$. However, both PFS (2.9 months vs 1.5 months; $\mathrm{HR}=0.53, p=0.04$ ) and OS (12.6 months vs 3.8 months; HR $=0.37, p$ $=0.002$ ) were improved for the 66 MET-positive (immunohistochemistry diagnostic positive) patients that were treated with erlotinib plus onartuzumab. Conversely, worse clinical outcomes were occurred in 62 MET-negative (immunohistochemistry diagnostic negative) patients that received onartuzumab plus erlotinib (PFS: 1.4 months vs 2.7 months; $\mathrm{HR}=1.82$, $p=0.05$; OS: 8.1 months vs 15.3 months; $\mathrm{HR}=1.78$, $p=0.16)$. Incidence of peripheral edema was observed in onartuzumab-treated patients with increased trend [108]. Another phase II study showed the same trend upon onartuzumab treatment for NSCLC: 109 patients with advanced squamous NSCLC were randomly assigned to treat with onartuzumab plus chemotherapy (paclitaxel plus carboplatin/cisplatin) or placebo plus chemotherapy. Similar results were obtained between onartuzumab plus chemotherapy and placebo plus chemotherapy in term of the risk of disease progression or death in ITT (stratified HR $=0.95,95 \%$ CI $=0.63-$ 1.43) and MET immunohistochemistry diagnostic positive $\left(\mathrm{IHC}^{+}\right)$populations (unstratified $\mathrm{HR}=1.27 ; 95 \%$ $\mathrm{CI}=0.69-2.32)$. The grade 3 to 5 adverse events (neutropenia and pulmonary embolism) were observed $14.8 \%$ and $5.8 \%$ in the onartuzumab plus chemotherapy and in the placebo plus chemotherapy, respectively [109].

\section{Cabozantinib (XL-184)}

Cabozantinib is a multi-kinase inhibitor targeting MET and VEGFR2. In a phase II study, patients with NSCLC were randomized to treat with cabozantinib alone (100 $\mathrm{mg}$ /day) or cabozantinib (100 mg/day) plus erlotinib (50 mg/day). The ORR was $6.7 \%(90 \% \mathrm{CI}=0.3-27.9)$ 
Table 1: Targeted therapies for NSCLC

\begin{tabular}{|c|c|c|c|}
\hline Inhibitor(s) & Target(s) & $\begin{array}{l}\text { Clinical trial } \\
\text { (Phase) }\end{array}$ & Reference(s) \\
\hline Gefitinib & $\begin{array}{l}\text { EGFR mutation: exon } 19 \text { deletions or exon } 21 \\
\left(E G F R^{L 858 R}\right) \text { mutations }\end{array}$ & III & {$[34]$} \\
\hline Erlotinib & $\begin{array}{l}\text { EGFR mutation: exon } 19 \text { deletions or exon } 21 \\
\left(E G F R^{L 858 R}\right) \text { mutations }\end{array}$ & II & [40] \\
\hline Icotinib & $\begin{array}{l}\text { EGFR mutation: exon } 19 \text { deletions or exon } 21 \\
\left(E G F R^{L 858 R}\right) \text { mutations }\end{array}$ & III & [41] \\
\hline Afatinib & $\begin{array}{l}\text { WT EGFR and EGFR mutation: exon } 19 \text { deletions } \\
\text { or exon } 21\left(E G F R^{L 858 R}\right) \text { mutations }\end{array}$ & III & {$[44,45]$} \\
\hline Dacomitinib & $\begin{array}{l}\text { WT EGFR and EGFR mutation: exon } 19 \text { deletions } \\
\text { or exon } 21\left(E G F R^{L 858 R}\right) \text { mutations }\end{array}$ & II, III & {$[49,50]$} \\
\hline Osimertinib & $E G F R^{T 790 M}$ mutation & II, III & [56] \\
\hline CT16 & EGFR, Notch $2 / 3$ & - & - \\
\hline PX-866 & PI3K & II & [63] \\
\hline Pictilisib & PI3K & I & {$[65]$} \\
\hline Buparlisib & PI3K & II & [67] \\
\hline Sirolimus & mTOR & I & {$[71]$} \\
\hline Everolimus & mTOR & II & {$[72,73]$} \\
\hline Ridaforolimus & mTOR & II & {$[74]$} \\
\hline Neratinib & $\begin{array}{l}\text { ErbB2 amplification: the long arm of chromosome } \\
17(17 \mathrm{q} 21)\end{array}$ & $\mathrm{I}, \mathrm{II}$ & {$[82,83]$} \\
\hline Lapatinib & EGFR, HER2 & II & {$[84]$} \\
\hline Bevacizumab & VEGFR & II, III & {$[89,90]$} \\
\hline sorafenib & VEGFR & II & {$[91,92]$} \\
\hline sunitinib & VEGFR, KIT, PDGFR, FLT3, RET & III & {$[94,95]$} \\
\hline Antroquinonol & KRAS mutation & I & {$[103]$} \\
\hline Tivantinib & c-MET amplification & III & [107] \\
\hline Onartuzumab & c-MET amplification & II & {$[108,109]$} \\
\hline Cabozantinib & c-MET, VEGFR & II & [110] \\
\hline Su112749 & c-MET amplification & - & - \\
\hline PHA-665752 & c-MET amplification & - & - \\
\hline Crizotinib & ALK fusion & II, III & {$[123,124]$} \\
\hline Alectinib & ALK fusion & II & {$[126,127]$} \\
\hline Ceritinib & ALK fusion & II & {$[128,129]$} \\
\hline Dabrafenib & BRAF V600E & II & {$[136,137]$} \\
\hline
\end{tabular}

Molecular targets, corresponding inhibitors and clinical trials are included.

in the cabozantinib alone $(n=15)$ with no responses in cabozantinib plus erlotinib $(n=13)$ [110]. There was no evidence to show that combination of cabozantinib plus erlotinib significantly sensitizes cabozantinib in patients with NSCLC.

\section{Su11274}

Su11274, the c-MET-specific TKI, in combination with EGFR TKIs were used to treat NSCLC cells. One of recent studies showed that su11274 potentiated the ability of afatinib against $E G F R^{T 790 M} \mathrm{H} 1975$ cells [111]. This study has provided evidences that combined inhibition of c-MET and EGFR would be a good clinical treatment strategy for NSCLC patients.

PHA-665752

PHA-665752 is a small molecule, inhibitor of c-MET kinase. PHA-665752 dramatically suppresses 
Table 2: Results of clinical trails

\begin{tabular}{|c|c|c|c|c|c|c|c|c|c|c|}
\hline \multirow[b]{2}{*}{ Inhibitor } & \multirow[b]{2}{*}{$\begin{array}{l}\text { Subjects } \\
(N)\end{array}$} & \multicolumn{3}{|c|}{ PFS } & \multicolumn{3}{|c|}{ OS } & \multicolumn{3}{|c|}{ ORR } \\
\hline & & $\begin{array}{c}\text { Time } \\
\text { (month) }\end{array}$ & $\begin{array}{c}p- \\
\text { value }\end{array}$ & $\begin{array}{c}95 \% \\
\text { CI }\end{array}$ & $\begin{array}{c}\text { Time } \\
\text { (month) }\end{array}$ & $\begin{array}{c}p- \\
\text { value }\end{array}$ & $\begin{array}{c}95 \% \\
\text { CI }\end{array}$ & $\begin{array}{l}\text { Rate } \\
(\%)\end{array}$ & $\begin{array}{c}p \text { - } \\
\text { value }\end{array}$ & $\begin{array}{c}95 \% \\
\text { CI }\end{array}$ \\
\hline Gefitinib & 261 & 10.9 & 0.001 & $0.4-0.8$ & - & - & - & 67.0 & 0.0004 & $1.6-5.5$ \\
\hline Erlotinib & 154 & 16.0 & 0.002 & $13.9-18.1$ & - & - & - & - & - & - \\
\hline Icotinib & 400 & 4.6 & 0.1 & $3.5-6.3$ & 13.3 & - & $11.1-16.2$ & 62.1 & 0.5 & $0.5-3.8$ \\
\hline Afatinib & 910 & 11.0 & $<0.0001$ & $9.7-13.7$ & 22.1 & 0.8 & $\begin{array}{l}20.0 \text {-not } \\
\text { estimable }\end{array}$ & 66.9 & $<0.0001$ & $4.3-12.2$ \\
\hline Dacomitinib & 121 & 14.6 & 0.2 & $9.0-18.2$ & 26.6 & - & $20.1-29.0$ & 62.1 & - & $0.5-0.7$ \\
\hline Osimertinib & ongoing & ongoing & ongoing & ongoing & ongoing & ongoing & ongoing & ongoing & ongoing & ongoing \\
\hline PX-866 & 95 & 2.0 & 0.7 & - & 7.0 & 0.9 & - & 6.0 & 0.4 & - \\
\hline Buparlisib & 63 & 3.0 & - & $9.9-42.3$ & 8.0 & - & $6.0-10.1$ & 3.3 & - & $0.1-7.2$ \\
\hline Sirolimus & 39 & 3.4 & - & $1.8-6.3$ & - & - & - & - & - & - \\
\hline Everolimus & 133 & 2.9 & 0.2 & $2.4-3.9$ & 9.1 & - & $7.5-11.1$ & - & - & - \\
\hline Ridaforolimus & 28 & 4.0 & 0.01 & - & 18.0 & 0.09 & - & - & - & - \\
\hline Neratinib & 167 & 15.3 & - & $14.7-15.9$ & - & - & - & - & - & - \\
\hline Lapatinib & 75 & 3.7 & - & - & 14.5 & - & - & - & - & - \\
\hline Bevacizumab & 297 & 4.6 & 0.003 & $2.3-9.4$ & 10.4 & 0.03 & $7.5-13.1$ & 38.0 & 0.01 & - \\
\hline sorafenib & 168 & 3.4 & 0.2 & $0.6-1.2$ & 6.7 & 8.0 & 0.19 & 8.0 & 0.6 & - \\
\hline sunitinib & 960 & 3.6 & 0.002 & $0.7-0.9$ & 9.0 & 0.2 & $0.8-1.1$ & 10.6 & 0.05 & - \\
\hline Tivantinib & 1048 & 3.6 & 0.001 & $0.6-0.9$ & 8.5 & 0.8 & $0.8-1.2$ & - & - & - \\
\hline Onartuzumab & 137 & 2.9 & 0.04 & - & 12.6 & 0.002 & - & 5.8 & - & - \\
\hline Cabozantinib & 65 & 3.9 & - & $1.5-7.3$ & - & - & - & 6.7 & - & $0.3-27.9$ \\
\hline Crizotinib & 343 & 10.9 & $<0.001$ & $0.4-0.6$ & 17.4 & 0.4 & $0.5-1.3$ & 74.0 & $<0.001$ & - \\
\hline Alectinib & 87 & 8.1 & - & $6.2-11.6$ & 12.0 & - & $61.0-88.0$ & 48.0 & - & $0.4-0.6$ \\
\hline Ceritinib & 140 & 5.7 & - & $5.4-7.6$ & 14.9 & - & $\begin{array}{l}\text { 13.5-not } \\
\text { estimable }\end{array}$ & 38.6 & - & $0.3-0.5$ \\
\hline Dabrafenib & 84 & 5.5 & - & $3.4-7.3$ & 12.7 & - & $7.3-16.9$ & 33.0 & - & $0.2-0.5$ \\
\hline
\end{tabular}

The results of molecular target inhibitors of NSCLC are summarized including PFS, OS and ORR.

tumor growth, as well as angiogenesis, in mouse NCI-H441 xenografts model [112]. The study suggested that PHA665752 may be a novel inhibitor of lung cancer. Additional clinical trials of PHA-665752 for NSCLC are required in the future.

\section{ALK fusion and ALK inhibitors}

\section{ALK fusion}

Anaplastic lymphoma kinase (ALK), a tyrosine kinase receptor, was found in anaplastic large-cell lymphoma (ALCL) cell lines in 1994 as a member of the insulin receptor superfamily which was closely associated with both solid and hematological tumors [113]. ALK gene rearrangements have described in NSCLC. The echinoderm microtubuleassociated protein-like 4 gene and the anaplastic lymphoma kinase gene (EML4-ALK) fusion oncogene was identified as a novel effective target in NSCLC in 2007 which has been detected in 5\% NSCLC patients [114-116]. EML4ALK fusions have been manifested to be mutually exclusive with EGFR or KRAS mutation found in patients without smoking history [117, 118]. However, drug resistance has been identified for crizotinib which was contributed by secondary mutations and therefore activation of either a bypass signal pathway (KIT or EGFR), or the ALK gene itself (such as F1174L, L1196M, C1156Y, G1269A, S1206Y, and G1202R), or gene amplification [119, 120].

\section{ALK inhibitors}

\section{Crizotinib}

Crizotinib, as a first generation ALK tyrosine kinase inhibitor, has been approved by US FDA in 2014 [121]. Crizotinib showed highly efficacy in NSCLC patient with ALK rearrangements, targeting ALK, MET, ROS1 [122]. In a single-arm, open-label, phase I-II study, 
NSCLC patients harboring ALK rearrangements (phase I, $n=24$; phase II, $n=46$ ) were given crizotinib (phase I, 20-300 mg/bid; phase II, 300 mg/bid). In Phase I, no adverse events of grade 4 were founded up to the highest dose. In Phase II, the objective response rate was 93.5\% $(n=43,95 \% \mathrm{CI}=82.1-98.6)$. Adverse events of grade 3 were noted in 12 of 46 patients, and no grade 4 adverse events or deaths were recorded [123]. In another phase 3 trial, 343 patients with advanced ALK-positive nonsquamous NSCLC were randomly assigned to receive crizotinib $(250 \mathrm{mg} / \mathrm{bid})$ or chemotherapy (pemetrexed or plus either cisplatin, or carboplatin). The median PFS was significantly longer in crizotinib group than in chemotherapy group (10.9 months vs. 7.0 months, $\mathrm{HR}=0.45,95 \% \mathrm{CI}=0.35-0.60 ; p<0.001)$. Patients in crizotinib group showed highly reduction in lung cancer symptoms and better improvement in quality of life [124].

\section{Alectinib}

Alectinib, as a second-generation highly selective small-molecule ALK inhibitors, shows great efficacy for overcoming crizotinib resistance in NSCLC patients with ALK rearrangements [125]. In a phase II study, 87 patients had received prior crizotinib therapy were randomly assigned to receive alectinib. The ORR was $48 \%$ (95\% $\mathrm{CI}=0.36-0.60$ ). Grade 1 or 2 adverse events (peripheral edema, myalgia, fatigue and constipation) were observed in this study [126]. Alectinib also showed effective in the 3-year follow-up of phase II: patients with ALK positive NSCLC received alectinib (300 mg//bid). The 3-year PFS rate was $62 \%(95 \% \mathrm{CI}=45-75)$ and $\mathrm{OS}$ rate was $78 \%$ [127].

\section{Ceritinib}

Ceritinib is another ALK inhibitor which has been approved by FDA in 2014. It shows great clinical efficacy against crizotinib-resistant ALK-positive tumors. In a Multicenter Phase II Study, 140 patients with advanced ALK-rearranged NSCLC who had been previously treated with crizotinib were randomly assigned to given ceritinib. The median PFS was 5.7 months $(95 \% \mathrm{CI}=5.4-7.6)$, the overall response rate was $38.6 \%(95 \% \mathrm{CI}=0.30-0.47)$ and disease control rate was $77.1 \%(95 \% \mathrm{CI}=0.69-0.84)$ [128]. In another Open-Label, Multicenter, Phase II Study, 32 patients with advanced ALK-positive NSCLC were randomly assigned to receive ceritinib $(750 \mathrm{mg} /$ day $)$. The median PFS and median OS were 9.3 months (95\% $\mathrm{CI}=0-22)$ and 24 months $(95 \% \mathrm{CI}=5-43)$, respectively. The ORR was $62 \%(95 \% \mathrm{CI}=0.45-0.77)$ and the duration of response was 21.0 months $(95 \% \mathrm{CI}=17-25)$; DCR was $81 \%(95 \% \mathrm{CI}=0.65-0.91)$ [129].

\section{BRAF mutation and BRAF inhibitor}

\section{BRAF mutation}

vRaf murine sarcoma viral oncogene homolog B (BRAF), as a proto-oncogene, encodes a serine/threonine protein kinase that promotes cell survival and proliferation [130]. BRAF mutations have been identified in a wide range of malignancies including $10 \%$ of colorectal carcinoma [131], and 50\% of malignant melanomas [132]. The BRAF Val600Glu (V600E) mutation were commonly seen in BRAF mutations that had been mainly found approximately $90 \%$ of melanoma [133]. The frequency of BRAF V600E mutation in NSCLC is about $1 \%-3 \%$ [134].

\section{BRAF inhibitor}

\section{Dabrafenib (GSK2118436)}

Dabrafenib, as an oral selective BRAF inhibitor [135]. Dabrafenib has shown activity in patients with advanced NSCLC harboring the BRAF V600E mutation. In a phase II study, 84 advanced NSCLC patients with BRAF V600E mutation were treated with dabrafenib $(150 \mathrm{mg} / \mathrm{bid})$. The median PFS of this study was 5.5 months $(95 \%$ $\mathrm{CI}=3.4-7.3)$ and the $\mathrm{ORR}$ was $33 \%(95 \% \mathrm{CI}=0.23-0.45)$. The median OS was 12.7 months $(95 \% \mathrm{CI}=7.3-16.9)$ [136]. However, combining dabrafenib with trametinib (a MEK inhibitor) may reveal a more effective treatment strategy. In an open-label, phase II trial, 36 advanced NSCLC patients with BRAF V600E mutation patients were randomly assigned to receive dabrafenib plus trametinib. The median OS was 24.6 months $(95 \% \mathrm{CI}=12.3-$ not estimable) and the ORR was $64 \%$ [137].

\section{CONCLUSIONS AND PERSPECTIVES}

Recently, a series of achievements have been made in NSCLC treatment with the better understanding of the molecular biology of NSCLC. Molecular targeted therapy based on targeting specificity can improve treatment safety and efficiency for NSCLC patients (Tables 1 and 2), although there are still challenges in development and application of targeted drugs. First of all, the efficacy of targeted drugs is yet to be improved alone with the potential side effects of the drugs; secondly, effective drug combinations hold promise and await further development. Furthermore, acquired resistance needs to be dealt with great efforts due to the constant occurrence after targeted therapies. With concerted efforts in these fields, the ultimate goal of achieving effective and harmless NSCLC therapy may be achievable.

\section{Abbreviations}

NSCLC: Non-small cell lung cancer; EGFR: Epidermal growth factor receptor; PI3K: 
Phosphatidylinositol 3-kinases; mTOR: Mechanistic target of rapamycin; ErbB2: Epidermal growth factor receptor 2; VEGF: Vascular endothelial growth factor; VEGFR: Vascular endothelial growth factor receptor; RAS: Human rat sarcoma protein; KRAS: Kirsten human rat sarcoma protein; c-MET: Mesenchymal-epithelial transition factor or hepatocyte growth factor receptor; PFS: Progression free survival; OS: Median overall survival; RFS: Recurrence-free survival; HR: Hazard Ratio; CI: Confidence interval; TKI: Tyrosine kinase inhibitor; FDA: Food and Drug Administration; DoR: Duration of response; IPASS: Iressa Pan-ASia Study; ITT: Intent-to-treat; OR: Odds ratio; ORR: Objective response rate; US: United States; CFDA: China Food and Drug Administration; MEK: Mitogen-activated protein kinase; DCR: Disease control rate; MAPK10: Mitogen activated protein kinase 10; PIM-1: Polymer of intrinsic microporosity; DHODH: Dihydroorotate dehydrogenase; ERBB-4: Epidermal growth factor receptor 4; HSD17B1: $17 \beta$ Hydroxysteroid dehydrogenase type 1; CHK2: Checkpoint kinase-2; CHK1: Checkpoint kinase-1; Bcl-2: B-cell lymphoma-2; Bcl-xl: B-cell lymphoma-xl; Mcl-1: Myeloid cell leukemia; LC3: Light chain 3; ERK: Extracellular Signal-regulated Kinase; RAF: Rapidly accelerated fibrosarcoma; JAK: Janus kinase; Shc: Generic shell script compiler; Src: Steroid receptor coactivator; GSK-3: Glycogen synthase kinase 3; Bmi: Body mass index; STAT3: Signal transducer and activator of transcription 3; DNA: Deoxyribonucleic acid; RNA: Ribonucleic acid; PDGFR: Platelet-derived growth factor; FLT3: Fms-like tyrosine kinase 3; ALK-anaplastic lymphoma kinase; BRAF-V-Raf murine sarcoma viral oncogene homolog B.

\section{ACKNOWLEDGMENTS}

This study was funded by grants from the One Hundred Talents Program of Hunan Province (No.2015ZSD).

\section{CONFLICTS OF INTEREST}

The authors have all declared there is no potential conflicts of interests are disclosed.

\section{REFERENCES}

1. Torre LA, Bray F, Siegel RL, Ferlay J, Lortet-Tieulent J, Jemal A. Global cancer statistics, 2012. CA Cancer J Clin. 2015; 65:87-108

2. Silvestri GA, Rivera MP. Targeted therapy for the treatment of advanced non-small cell lung cancer: a review of the epidermal growth factor receptor antagonists. Chest. 2005; 128:3975-84.
3. Tarver T. Cancer Facts \& Figures 2012. American Cancer Society (ACS). Atlanta (GA): American Cancer Society; 2012. https://doi.org/10.1080/15398285.2012.701177.

4. Tas F, Yildiz I, Kilic L, Ciftci R, Keskin S, Sen F. Same chemotherapy regimen leads to different myelotoxicity in different malignancies: a comparison of chemotherapy-associated myelotoxicity in patients with advanced ovarian and non-small-cell lung cancer. Am J Ther. 2016; 23:e670-79.

5. Tang C, Qin S, Wu W, Wu Y, Zhang T. Efficacy and potential application of neoadjuvant chemotherapy in patients with iiia stage non-small cell lung cancer. Zhongguo Fei Ai Za Zhi. 2017; 20:100-06.

6. Rossi A, La Salvia A, Di Maio M. Chemotherapy and intercalated gefitinib or erlotinib in the treatment of advanced non-small-cell lung cancer. Expert Rev Respir Med. 2017; 11:171-80.

7. Trimmer EE, Essigmann JM. Cisplatin. Essays Biochem. 1999; 34:191-211.

8. Barry MA, Behnke CA, Eastman A. Activation of programmed cell death (apoptosis) by cisplatin, other anticancer drugs, toxins and hyperthermia. Biochem Pharmacol. 1990; 40:2353-62.

9. Pignon JP, Tribodet H, Scagliotti GV, Douillard JY, Shepherd FA, Stephens RJ, Dunant A, Torri V, Rosell R, Seymour L, Spiro SG, Rolland E, Fossati R, et al, and LACE Collaborative Group. Lung adjuvant cisplatin evaluation: a pooled analysis by the LACE Collaborative Group. J Clin Oncol. 2008; 26:3552-59.

10. Scagliotti GV, Parikh P, von Pawel J, Biesma B, Vansteenkiste J, Manegold C, Serwatowski P, Gatzemeier U, Digumarti R, Zukin M, Lee JS, Mellemgaard A, Park $\mathrm{K}$, et al. Phase III study comparing cisplatin plus gemcitabine with cisplatin plus pemetrexed in chemotherapy-naive patients with advanced-stage non-small-cell lung cancer. J Clin Oncol. 2008; 26:3543-51.

11. Grønberg BH, Bremnes RM, Fløtten $\mathrm{O}$, Amundsen $\mathrm{T}$, Brunsvig PF, Hjelde HH, Kaasa S, von Plessen C, Stornes F, Tollåli T, Wammer F, Aasebø U, Sundstrøm S. Phase III study by the Norwegian lung cancer study group: pemetrexed plus carboplatin compared with gemcitabine plus carboplatin as first-line chemotherapy in advanced non-small-cell lung cancer. J Clin Oncol. 2009; 27:3217-24.

12. Pirker R, Pereira JR, Szczesna A, von Pawel J, Krzakowski M, Ramlau R, Vynnychenko I, Park K, Yu CT, Ganul V, Roh JK, Bajetta E, O'Byrne K, et al, and FLEX Study Team. Cetuximab plus chemotherapy in patients with advanced non-small-cell lung cancer (FLEX): an open-label randomised phase III trial. Lancet. 2009; 373:1525-31.

13. Brade A, MacRae R, Laurie SA, Bezjak A, Burkes R, Chu Q, Goffin JR, Cho J, Hope A, Sun A, Leighl N, Capobianco $\mathrm{S}$, Feld R, et al. Phase II study of concurrent pemetrexed, cisplatin, and radiation therapy for stage $\mathrm{iiia} / \mathrm{b}$ unresectable non-small cell lung cancer. Clin Lung Cancer. 2016; $17: 133-41$ 
14. Moisan F, Francisco EB, Brozovic A, Duran GE, Wang YC, Chaturvedi S, Seetharam S, Snyder LA, Doshi P, Sikic BI. Enhancement of paclitaxel and carboplatin therapies by CCL2 blockade in ovarian cancers. Mol Oncol. 2014; 8:1231-39.

15. Megerdichian C, Olimpiadi Y, Hurvitz SA. nab-Paclitaxel in combination with biologically targeted agents for early and metastatic breast cancer. Cancer Treat Rev. 2014; 40:614-25.

16. Zhang S, Mercado-Uribe I, Liu J. Tumor stroma and differentiated cancer cells can be originated directly from polyploid giant cancer cells induced by paclitaxel. Int J Cancer. 2014; 134:508-18.

17. Lin H, Chen Y, Shi A, Pandya KJ, Yu R, Yuan Y, Li J, Li H, Wang Y, Xia T, Feng L, Ma H, Geng J, Zhu G. Phase 3 randomized low-dose paclitaxel chemoradiotherapy study for locally advanced non-small cell lung cancer. Front Oncol. 2016; 6:260.

18. Hoskins P, Vergote I, Cervantes A, Tu D, Stuart G, Zola P, Poveda A, Provencher D, Katsaros D, Ojeda B, Ghatage P, Grimshaw R, Casado A, et al. Advanced ovarian cancer: phase III randomized study of sequential cisplatin-topotecan and carboplatin-paclitaxel vs carboplatin-paclitaxel. J Natl Cancer Inst. 2010; 102:1547-56.

19. Lorusso V, Crucitta E, Silvestris N, Rosati G, Manzione L, De Lena M, Palmeri S, Gebbia V, Mancarella S, Sobrero A, Pezzella G, Comella P, Mangiameli A, Muci D, and Italian Bladder Cancer Group. Randomised, open-label, phase II trial of paclitaxel, gemcitabine and cisplatin versus gemcitabine and cisplatin as first-line chemotherapy in advanced transitional cell carcinoma of the urothelium. Oncol Rep. 2005; 13:283-87.

20. Merouani A, Davidson SA, Schrier RW. Increased nephrotoxicity of combination taxol and cisplatin chemotherapy in gynecologic cancers as compared to cisplatin alone. Am J Nephrol. 1997; 17:53-58.

21. Wu Y, Feng J, Hu W, Luo Q. A randomized placebo-controlled clinical study of nab-paclitaxel as second-line chemotherapy for patients with advanced non-small cell lung cancer in China. Biosci Rep. 2017; 37:BSR20170020.

22. Gazdar AF. Activating and resistance mutations of EGFR in non-small-cell lung cancer: role in clinical response to EGFR tyrosine kinase inhibitors. Oncogene. 2009; 28:S24-S31.

23. Gazdar AF, Minna JD. Deregulated EGFR signaling during lung cancer progression: mutations, amplicons, and autocrine loops. Cancer Prev Res (Phila). 2008; 1:156-60.

24. Paez JG, Jänne PA, Lee JC, Tracy S, Greulich H, Gabriel S, Herman P, Kaye FJ, Lindeman N, Boggon TJ, Naoki $\mathrm{K}$, Sasaki H, Fujii Y, et al. EGFR mutations in lung cancer: correlation with clinical response to gefitinib therapy. Science. 2004; 304:1497-500.

25. Sharma SV, Bell DW, Settleman J, Haber DA. Epidermal growth factor receptor mutations in lung cancer. Nat Rev Cancer. 2007; 7:169-81.
26. Eck MJ, Yun CH. Structural and mechanistic underpinnings of the differential drug sensitivity of EGFR mutations in non-small cell lung cancer. Biochim Biophys Acta. 2010; 1804:559-66.

27. Rothschild SI, Gautschi O. Crizotinib in the treatment of non-small-cell lung cancer. Clin Lung Cancer. 2013; 14:473-80.

28. Kowalski DM, Krzakowski M, Ramlau R, Jaskiewicz P, Janowicz-Żebrowska A. Erlotinib in salvage treatment of patients with advanced non-small cell lung cancer: results of an expanded access programme in Poland. Contemp Oncol (Pozn). 2012; 16:170-75.

29. Zhou Q, Zhang XC, Chen ZH, Yin XL, Yang JJ, Xu CR, Yan HH, Chen HJ, Su J, Zhong WZ, Yang XN, An SJ, Wang $\mathrm{BC}$, et al. Relative abundance of EGFR mutations predicts benefit from gefitinib treatment for advanced non-small-cell lung cancer. J Clin Oncol. 2011; 29:3316-21.

30. Mok TS, Wu YL, Thongprasert S, Yang CH, Chu DT, Saijo N, Sunpaweravong P, Han B, Margono B, Ichinose Y, Nishiwaki Y, Ohe Y, Yang JJ, et al. Gefitinib or carboplatin-paclitaxel in pulmonary adenocarcinoma. N Engl J Med. 2009; 361:947-57.

31. Balak MN, Gong Y, Riely GJ, Somwar R, Li AR, Zakowski MF, Chiang A, Yang G, Ouerfelli O, Kris MG, Ladanyi M, Miller VA, Pao W. Novel D761Y and common secondary T790M mutations in epidermal growth factor receptor-mutant lung adenocarcinomas with acquired resistance to kinase inhibitors. Clin Cancer Res. 2006; 12:6494-501.

32. Kosaka T, Yatabe Y, Endoh H, Yoshida K, Hida T, Tsuboi M, Tada H, Kuwano H, Mitsudomi T. Analysis of epidermal growth factor receptor gene mutation in patients with nonsmall cell lung cancer and acquired resistance to gefitinib. Clin Cancer Res. 2006; 12:5764-69.

33. Kazandjian D, Blumenthal GM, Yuan W, He K, Keegan P, Pazdur R. FDA approval of gefitinib for the treatment of patients with metastatic EGFR mutation-positive non-small cell lung cancer. Clin Cancer Res. 2016; 22:1307-12.

34. Wu YL, Saijo N, Thongprasert S, Yang JC, Han B, Margono B, Chewaskulyong B, Sunpaweravong P, Ohe Y, Ichinose Y, Yang JJ, Mok TS, Young H, et al. Efficacy according to blind independent central review: post-hoc analyses from the phase III, randomized, multicenter, IPASS study of firstline gefitinib versus carboplatin/paclitaxel in Asian patients with EGFR mutation-positive advanced NSCLC. Lung Cancer. 2017; 104:119-25.

35. Cohen MH, Williams GA, Sridhara R, Chen G, McGuinn WD Jr, Morse D, Abraham S, Rahman A, Liang C, Lostritto R, Baird A, Pazdur R. United states food and drug administration drug approval summary: gefitinib (ZD1839; iressa) tablets. Clin Cancer Res. 2004; 10:1212-18.

36. Verma N, Rai AK, Kaushik V, Brünnert D, Chahar KR, Pandey J, Goyal P. Identification of gefitinib off-targets using a structure-based systems biology approach; their validation with reverse docking and retrospective data mining. Sci Rep. 2016; 6:33949. 
37. Moretti L, Li B, Kim KW, Chen H, Lu B. AT-101, a panBcl-2 inhibitor, leads to radiosensitization of non-small cell lung cancer. J Thorac Oncol. 2010; 5:680-87.

38. Zhao R, Zhou S, Xia B, Zhang CY, Hai P, Zhe H, Wang YY. AT-101 enhances gefitinib sensitivity in non-small cell lung cancer with EGFR T790M mutations. BMC Cancer. 2016; $16: 491$.

39. Khozin S, Blumenthal GM, Jiang X, He K, Boyd K, Murgo A, Justice R, Keegan P, Pazdur R. U.S. Food and Drug Administration approval summary: erlotinib for the firstline treatment of metastatic non-small cell lung cancer with epidermal growth factor receptor exon 19 deletions or exon 21 (L858R) substitution mutations. Oncologist. 2014; 19:774-79.

40. Seto T, Kato T, Nishio M, Goto K, Atagi S, Hosomi Y, Yamamoto N, Hida T, Maemondo M, Nakagawa K, Nagase S, Okamoto I, Yamanaka T, et al. Erlotinib alone or with bevacizumab as first-line therapy in patients with advanced non-squamous non-small-cell lung cancer harbouring EGFR mutations (JO25567): an open-label, randomised, multicentre, phase 2 study. Lancet Oncol. 2014; 15:1236-44.

41. Shi Y, Zhang L, Liu X, Zhou C, Zhang L, Zhang S, Wang D, Li Q, Qin S, Hu C, Zhang Y, Chen J, Cheng Y, et al. Icotinib versus gefitinib in previously treated advanced nonsmall-cell lung cancer (ICOGEN): a randomised, doubleblind phase 3 non-inferiority trial. Lancet Oncol. 2013; 14:953-61.

42. Hu X, Zhang L, Shi Y, Zhou C, Liu X, Wang D, Song Y, Li Q, Feng J, Qin S, Xv N, Zhou J, Zhang L, et al. The efficacy and safety of icotinib in patients with advanced non-small cell lung cancer previously treated with chemotherapy: a single-arm, multi-center, prospective study. PLoS One. 2015; 10:e142500.

43. Le AD, Alzghari SK, Jean GW, La-Beck NM. Update on targeted therapies for advanced non-small cell lung cancer: nivolumab in context. Ther Clin Risk Manag. 2017; 13:223-36.

44. Wu YL, Zhou C, Hu CP, Feng J, Lu S, Huang Y, Li W, Hou M, Shi JH, Lee KY, Xu CR, Massey D, Kim M, et al. Afatinib versus cisplatin plus gemcitabine for first-line treatment of Asian patients with advanced non-small-cell lung cancer harbouring EGFR mutations (LUX-Lung 6): an open-label, randomised phase 3 trial. Lancet Oncol. 2014; 15:213-22.

45. Sequist LV, Yang JC, Yamamoto N, O'Byrne K, Hirsh V, Mok T, Geater SL, Orlov S, Tsai CM, Boyer M, Su WC, Bennouna J, Kato T, et al. Phase III study of afatinib or cisplatin plus pemetrexed in patients with metastatic lung adenocarcinoma with EGFR mutations. J Clin Oncol. 2013; 31:3327-34.

46. Chen G, Noor A, Kronenberger P, Teugels E, Umelo IA, De Grève J. Synergistic effect of afatinib with su11274 in nonsmall cell lung cancer cells resistant to gefitinib or erlotinib. PLoS One. 2013; 8:e59708.
47. Miller VA, Hirsh V, Cadranel J, Chen YM, Park K, Kim SW, Zhou C, Su WC, Wang M, Sun Y, Heo DS, Crino L, Tan EH, et al. Afatinib versus placebo for patients with advanced, metastatic non-small-cell lung cancer after failure of erlotinib, gefitinib, or both, and one or two lines of chemotherapy (LUX-Lung 1): a phase $2 \mathrm{~b} / 3$ randomised trial. Lancet Oncol. 2012; 13:528-38.

48. Katakami N, Atagi S, Goto K, Hida T, Horai T, Inoue A, Ichinose Y, Koboyashi K, Takeda K, Kiura K, Nishio K, Seki Y, Ebisawa R, et al. LUX-Lung 4: a phase II trial of afatinib in patients with advanced non-small-cell lung cancer who progressed during prior treatment with erlotinib, gefitinib, or both. J Clin Oncol. 2013; 31:3335-41.

49. Reckamp KL, Giaccone G, Camidge DR, Gadgeel SM, Khuri FR, Engelman JA, Koczywas M, Rajan A, Campbell AK, Gernhardt D, Ruiz-Garcia A, Letrent S, Liang J, et al. A phase 2 trial of dacomitinib (PF-00299804), an oral, irreversible pan-HER (human epidermal growth factor receptor) inhibitor, in patients with advanced non-small cell lung cancer after failure of prior chemotherapy and erlotinib. Cancer. 2014; 120:1145-54.

50. Ramalingam SS, O’Byrne K, Boyer M, Mok T, Jänne PA, Zhang H, Liang J, Taylor I, Sbar EI, Paz-Ares L. Dacomitinib versus erlotinib in patients with EGFRmutated advanced nonsmall-cell lung cancer (NSCLC): pooled subset analyses from two randomized trials. Ann Oncol. 2016; 27:423-29.

51. Pao W, Miller VA, Politi KA, Riely GJ, Somwar R, Zakowski MF, Kris MG, Varmus H. Acquired resistance of lung adenocarcinomas to gefitinib or erlotinib is associated with a second mutation in the EGFR kinase domain. PLoS Med. 2005; 2:e73.

52. Kobayashi S, Boggon TJ, Dayaram T, Jänne PA, Kocher O, Meyerson M, Johnson BE, Eck MJ, Tenen DG, Halmos B. EGFR mutation and resistance of non-small-cell lung cancer to gefitinib. N Engl J Med. 2005; 352:786-92.

53. Thress KS, Paweletz CP, Felip E, Cho BC, Stetson D, Dougherty B, Lai Z, Markovets A, Vivancos A, Kuang Y, Ercan D, Matthews SE, Cantarini M, et al. Acquired EGFR C797S mutation mediates resistance to AZD9291 in nonsmall cell lung cancer harboring EGFR T790M. Nat Med. 2015; 21:560-62.

54. Remon J, Planchard D. AZD9291 in EGFR-mutant advanced non-small-cell lung cancer patients. Future Oncol. 2015; 11:3069-81.

55. Jänne PA, Yang JC, Kim DW, Planchard D, Ohe Y, Ramalingam SS, Ahn MJ, Kim SW, Su WC, Horn L, Haggstrom D, Felip E, Kim JH, et al. AZD9291 in EGFR inhibitor-resistant non-small-cell lung cancer. N Engl J Med. 2015; 372:1689-99.

56. Thress KS, Brant R, Carr TH, Dearden S, Jenkins S, Brown H, Hammett T, Cantarini M, Barrett JC. EGFR mutation detection in ctDNA from NSCLC patient plasma: A cross-platform comparison of leading technologies 
to support the clinical development of AZD9291. Lung Cancer. 2015; 90:509-15.

57. Hu S, Fu W, Li T, Yuan Q, Wang F, Lv G, Lv Y, Fan X, Shen Y, Lin F, Tang Y, Ye X, Yang Y, Lei C. Antagonism of EGFR and Notch limits resistance to EGFR inhibitors and radiation by decreasing tumor-initiating cell frequency. Sci Transl Med. 2017; 9:eaag0339.

58. Vivanco I, Sawyers CL. The phosphatidylinositol 3-Kinase AKT pathway in human cancer. Nat Rev Cancer. 2002; 2:489-501.

59. Samuels Y, Wang Z, Bardelli A, Silliman N, Ptak J, Szabo S, Yan H, Gazdar A, Powell SM, Riggins GJ, Willson JK, Markowitz S, Kinzler KW, et al. High frequency of mutations of the PIK3CA gene in human cancers. Science. 2004; 304:554.

60. Yamamoto H, Shigematsu H, Nomura M, Lockwood WW, Sato M, Okumura N, Soh J, Suzuki M, Wistuba II, Fong KM, Lee H, Toyooka S, Date H, et al. PIK3CA mutations and copy number gains in human lung cancers. Cancer Res. 2008; 68:6913-21.

61. Okudela K, Suzuki M, Kageyama S, Bunai T, Nagura K, Igarashi H, Takamochi K, Suzuki K, Yamada T, Niwa H, Ohashi R, Ogawa H, Mori H, et al. PIK3CA mutation and amplification in human lung cancer. Pathol Int. 2007; 57:664-71.

62. Ihle NT, Paine-Murrieta G, Berggren MI, Baker A, Tate WR, Wipf P, Abraham RT, Kirkpatrick DL, Powis G. The phosphoinositide-3-kinase inhibitor PX-866 overcomes resistance to the EGFR inhibitor gefitinib in A-549 human non small cell lung cancer xenografts. Mol Cancer Ther. 2005; 4:1349-57.

63. Levy B, Spira A, Becker D, Evans T, Schnadig I, Camidge DR, Bauman JE, Hausman D, Walker L, Nemunaitis J, Rudin CM, Halmos B, Bowles DW. A randomized, phase 2 trial of Docetaxel with or without PX-866, an irreversible oral phosphatidylinositol 3-kinase inhibitor, in patients with relapsed or metastatic non-small-cell lung cancer. J Thorac Oncol. 2014; 9:1031-35.

64. Shi F, Guo H, Zhang R, Liu H, Wu L, Wu Q, Liu J, Liu T, Zhang Q. The PI3K inhibitor GDC-0941 enhances radiosensitization and reduces chemoresistance to temozolomide in GBM cell lines. Neuroscience. 2017; 346:298-308.

65. Yamamoto N, Fujiwara Y, Tamura K, Kondo S, Iwasa S, Tanabe Y, Horiike A, Yanagitani N, Kitazono S, Inatani M, Tanaka J, Nishio M. Phase Ia/Ib study of the pan-class I PI3K inhibitor pictilisib (GDC-0941) administered as a single agent in Japanese patients with solid tumors and in combination in Japanese patients with non-squamous nonsmall cell lung cancer. Invest New Drugs. 2017; 35:37-46.

66. Ren H, Zhao L, Li Y, Yue P, Deng X, Owonikoko TK, Chen M, Khuri FR, Sun SY. The PI3 kinase inhibitor NVP-BKM120 induces GSK3/FBXW7-dependent Mcl-1 degradation, contributing to induction of apoptosis and enhancement of TRAIL-induced apoptosis. Cancer Lett. 2013; 338:229-38.

67. Vansteenkiste JF, Canon JL, De Braud F, Grossi F, De Pas T, Gray JE, Su WC, Felip E, Yoshioka H, Gridelli C, Dy GK, Thongprasert S, Reck M, et al. Safety and efficacy of buparlisib (BKM120) in patients with pi3k pathway-activated non-small cell lung cancer: results from the phase II basalt-1 study. J Thorac Oncol. 2015; 10:1319-27.

68. Yao W, Yue P, Zhang G, Owonikoko TK, Khuri FR, Sun SY. Enhancing therapeutic efficacy of the MEK inhibitor, MEK162, by blocking autophagy or inhibiting PI3K/Akt signaling in human lung cancer cells. Cancer Lett. 2015; 364:70-78.

69. Ren H, Guo H, Thakur A, Zhang S, Wang T, Liang Y, Shi P, Gao L, Liu F, Feng J, Chen T, Yang T, Shang D, et al. Blockade efficacy of MEK/ERK-dependent autophagy enhances PI3K/Akt inhibitor NVP-BKM120's therapeutic effectiveness in lung cancer cells. Oncotarget. 2016; 7:67277-87. https://doi.org/10.18632/oncotarget.11645.

70. Choi J, Chen J, Schreiber SL, Clardy J. Structure of the FKBP12-rapamycin complex interacting with the binding domain of human FRAP. Science. 1996; 273:239-42.

71. Moran T, Palmero R, Provencio M, Insa A, Majem M, Reguart N, Bosch-Barrera J, Isla D, Costa EC, Lee C, Puig M, Kraemer S, Schnell D, Rosell R. A phase Ib trial of continuous once-daily oral afatinib plus sirolimus in patients with epidermal growth factor receptor mutation-positive non-small cell lung cancer and/or disease progression following prior erlotinib or gefitinib. Lung Cancer. 2017; 108:154-60.

72. Ramalingam SS, Owonikoko TK, Behera M, Subramanian J, Saba NF, Kono SA, Gal AA, Sica G, Harvey RD, Chen Z, Klass CM, Shin DM, Fu H, et al. Phase II study of docetaxel in combination with everolimus for second- or third-line therapy of advanced non-small-cell lung cancer. J Thorac Oncol. 2013; 8:369-72.

73. Besse B, Leighl N, Bennouna J, Papadimitrakopoulou VA, Blais N, Traynor AM, Soria JC, Gogov S, Miller N, Jehl V, Johnson BE. Phase II study of everolimus-erlotinib in previously treated patients with advanced non-small-cell lung cancer. Ann Oncol. 2014; 25:409-15.

74. Gregory JR, Julie RB, David P, Lucio C, Robert CD, Luis AM, Scott NG, Christian S, Xiaoyun L, Barbara MA, Scot E, Rafael R. A randomized discontinuation phase II trial of ridaforolimus in non-small cell lung cancer (NSCLC) patients with KRAS mutations. J Clin Oncol. 2012; 30:7531.

75. Yarden Y, Sliwkowski MX. Untangling the ErbB signalling network. Nat Rev Mol Cell Biol. 2001; 2:127-37.

76. Giza DE, Vasilescu C, Calin GA. Key principles of miRNA involvement in human diseases. Discoveries (Craiova). 2014; 2:e34.

77. Hirsch FR, Varella-Garcia M, Franklin WA, Veve R, Chen L, Helfrich B, Zeng C, Baron A, Bunn PA Jr. Evaluation 
of HER-2/neu gene amplification and protein expression in non-small cell lung carcinomas. Br J Cancer. 2002; $86: 1449-56$.

78. Nakamura H, Kawasaki N, Taguchi M, Kabasawa K. Association of HER-2 overexpression with prognosis in nonsmall cell lung carcinoma: a metaanalysis. Cancer. 2005; 103:1865-73.

79. Mar N, Vredenburgh JJ, Wasser JS. Targeting HER2 in the treatment of non-small cell lung cancer. Lung Cancer. 2015; $87: 220-25$.

80. Shimamura T, Ji H, Minami Y, Thomas RK, Lowell AM, Shah K, Greulich H, Glatt KA, Meyerson M, Shapiro GI, Wong KK. Non-small-cell lung cancer and $\mathrm{Ba} / \mathrm{F} 3$ transformed cells harboring the ERBB2 G776insV_G/C mutation are sensitive to the dual-specific epidermal growth factor receptor and ERBB2 inhibitor HKI-272. Cancer Res. 2006; 66:6487-91.

81. Minami Y, Shimamura T, Shah K, LaFramboise T, Glatt KA, Liniker E, Borgman CL, Haringsma HJ, Feng W, Weir BA, Lowell AM, Lee JC, Wolf J, et al. The major lung cancer-derived mutants of ERBB2 are oncogenic and are associated with sensitivity to the irreversible EGFR/ERBB2 inhibitor HKI-272. Oncogene. 2007; 26:5023-27.

82. Sequist LV, Besse B, Lynch TJ, Miller VA, Wong KK, Gitlitz B, Eaton K, Zacharchuk C, Freyman A, Powell C, Ananthakrishnan R, Quinn S, Soria JC. Neratinib, an irreversible pan-ErbB receptor tyrosine kinase inhibitor: results of a phase II trial in patients with advanced non-small-cell lung cancer. J Clin Oncol. 2010; 28:3076-83.

83. Gandhi L, Bahleda R, Tolaney SM, Kwak EL, Cleary JM, Pandya SS, Hollebecque A, Abbas R, Ananthakrishnan R, Berkenblit A, Krygowski M, Liang Y, Turnbull KW, et al. Phase I study of neratinib in combination with temsirolimus in patients with human epidermal growth factor receptor 2-dependent and other solid tumors. J Clin Oncol. 2014; 32:68-75.

84. Ross HJ, Blumenschein GR Jr, Aisner J, Damjanov N, Dowlati A, Garst J, Rigas JR, Smylie M, Hassani H, Allen KE, Leopold L, Zaks TZ, Shepherd FA. Randomized phase II multicenter trial of two schedules of lapatinib as firstor second-line monotherapy in patients with advanced or metastatic non-small cell lung cancer. Clin Cancer Res. 2010; 16:1938-49.

85. Ferrara N, Gerber HP, LeCouter J. The biology of VEGF and its receptors. Nat Med. 2003; 9:669-76.

86. Folkman J. Role of angiogenesis in tumor growth and metastasis. Semin Oncol. 2002; 29:15-18.

87. Sandler A, Gray R, Perry MC, Brahmer J, Schiller JH, Dowlati A, Lilenbaum R, Johnson DH. Paclitaxelcarboplatin alone or with bevacizumab for non-small-cell lung cancer. N Engl J Med. 2006; 355:2542-50.

88. Naoki K, Takeda Y, Soejima K, Arai D, Naka G, Nagase S, Arimura K, Kanemura T, Ohhira T, Ikeda N. A prospective cohort study of patients with non-squamous non-small cell lung cancer treated with bevacizumab. Oncol Lett. 2017; 13:3285-90.

89. Jones BS, Jerome MS, Miley D, Jackson BE, DeShazo MR, Reddy VV, Singh KP, Brown OC, Robert F. Pilot phase II study of metronomic chemotherapy in combination with bevacizumab in patients with advanced non-squamous nonsmall cell lung cancer. Lung Cancer. 2017; 106:125-30.

90. Wang Y, Wang H, Jiang Y, Zhang Y, Wang X. A randomized phase III study of combining erlotinib with bevacizumab and panitumumab versus erlotinib alone as second-line therapy for Chinese patients with non-small-cell lung cancer. Biomed Pharmacother. 2017; 89:875-79.

91. Spigel DR, Burris HA 3rd, Greco FA, Shipley DL, Friedman EK, Waterhouse DM, Whorf RC, Mitchell RB, Daniel DB, Zangmeister J, Bass JD, Hainsworth JD. Randomized, double-blind, placebo-controlled, phase II trial of sorafenib and erlotinib or erlotinib alone in previously treated advanced non-small-cell lung cancer. J Clin Oncol. 2011; 29:2582-89.

92. Blumenschein GR Jr, Gatzemeier U, Fossella F, Stewart DJ, Cupit L, Cihon F, O’Leary J, Reck M. Phase II, multicenter, uncontrolled trial of single-agent sorafenib in patients with relapsed or refractory, advanced non-small-cell lung cancer. J Clin Oncol. 2009; 27:4274-80.

93. Faivre S, Demetri G, Sargent W, Raymond E. Molecular basis for sunitinib efficacy and future clinical development. Nat Rev Drug Discov. 2007; 6:734-45.

94. Scagliotti GV, Krzakowski M, Szczesna A, Strausz J, Makhson A, Reck M, Wierzbicki RF, Albert I, Thomas M, Miziara JE, Papai ZS, Karaseva N, Thongprasert S, et al. Sunitinib plus erlotinib versus placebo plus erlotinib in patients with previously treated advanced non-smallcell lung cancer: a phase III trial. J Clin Oncol. 2012; 30:2070-78.

95. Baggstrom MQ, Socinski MA, Wang XF, Gu L, Stinchcombe TE, Edelman MJ, Baker S Jr, Feliciano J, Novotny P, Hahn O, Crawford JA, Vokes EE. Maintenance sunitinib following initial platinum-based combination chemotherapy in advanced-stage IIIB/IV non-small cell lung cancer: a randomized, double-blind, placebo-controlled phase III Study-CALGB 30607 (Alliance). J Thorac Oncol. 2017; 12:843-49.

96. Galleges Ruiz MI, Floor K, Steinberg SM, Grünberg K, Thunnissen FB, Belien JA, Meijer GA, Peters GJ, Smit EF, Rodriguez JA, Giaccone G. Combined assessment of EGFR pathway-related molecular markers and prognosis of NSCLC patients. Br J Cancer. 2009; 100:145-52.

97. Rodenhuis S, Slebos RJ. Clinical significance of ras oncogene activation in human lung cancer. Cancer Res. 1992; $52: 2665 \mathrm{~s}-2669 \mathrm{~s}$.

98. Riely GJ, Marks J, Pao W. KRAS mutations in non-small cell lung cancer. Proc Am Thorac Soc. 2009; 6:201-05.

99. Santos E, Martin-Zanca D, Reddy EP, Pierotti MA, Della Porta G, Barbacid M. Malignant activation of a K-ras 
oncogene in lung carcinoma but not in normal tissue of the same patient. Science. 1984; 223:661-64.

100. Kumar KJ, Chu FH, Hsieh HW, Liao JW, Li WH, Lin JC, Shaw JF, Wang SY. Antroquinonol from ethanolic extract of mycelium of Antrodia cinnamomea protects hepatic cells from ethanol-induced oxidative stress through Nrf-2 activation. J Ethnopharmacol. 2011; 136:168-77.

101. Kumar VB, Yuan TC, Liou JW, Yang CJ, Sung PJ, Weng CF. Antroquinonol inhibits NSCLC proliferation by altering PI3K/mTOR proteins and miRNA expression profiles. Mutat Res. 2011; 707:42-52.

102. Ho CL, Wang JL, Lee CC, Cheng HY, Wen WC, Cheng HH, Chen MC. Antroquinonol blocks Ras and Rho signaling via the inhibition of protein isoprenyltransferase activity in cancer cells. Biomed Pharmacother. 2014; 68:1007-14.

103. Lee YC, Ho CL, Kao WY, Chen YM. A phase I multicenter study of antroquinonol in patients with metastatic nonsmall-cell lung cancer who have received at least two prior systemic treatment regimens, including one platinum-based chemotherapy regimen. Mol Clin Oncol. 2015; 3:1375-80.

104. Ma PC, Jagadeeswaran R, Jagadeesh S, Tretiakova MS, Nallasura V, Fox EA, Hansen M, Schaefer E, Naoki K, Lader A, Richards W, Sugarbaker D, Husain AN, et al. Functional expression and mutations of c-Met and its therapeutic inhibition with SU11274 and small interfering RNA in non-small cell lung cancer. Cancer Res. 2005; 65:1479-88.

105. Bean J, Brennan C, Shih JY, Riely G, Viale A, Wang L, Chitale D, Motoi N, Szoke J, Broderick S, Balak M, Chang WC, Yu CJ, et al. MET amplification occurs with or without T790M mutations in EGFR mutant lung tumors with acquired resistance to gefitinib or erlotinib. Proc Natl Acad Sci USA. 2007; 104:20932-37.

106. Engelman JA, Zejnullahu K, Mitsudomi T, Song Y, Hyland C, Park JO, Lindeman N, Gale CM, Zhao X, Christensen J, Kosaka T, Holmes AJ, Rogers AM, et al. MET amplification leads to gefitinib resistance in lung cancer by activating ERBB3 signaling. Science. 2007; 316:1039-43.

107. Scagliotti G, von Pawel J, Novello S, Ramlau R, Favaretto A, Barlesi F, Akerley W, Orlov S, Santoro A, Spigel D, Hirsh V, Shepherd FA, Sequist LV, et al. Phase III multinational, randomized, double-blind, placebo-controlled study of tivantinib (ARQ 197) plus erlotinib versus erlotinib alone in previously treated patients with locally advanced or metastatic nonsquamous non-small-cell lung cancer. J Clin Oncol. 2015; 33:2667-74.

108. Spigel DR, Ervin TJ, Ramlau RA, Daniel DB, Goldschmidt JH Jr, Blumenschein GR Jr, Krzakowski MJ, Robinet G, Godbert B, Barlesi F, Govindan R, Patel T, Orlov SV, et al. Randomized phase II trial of Onartuzumab in combination with erlotinib in patients with advanced non-small-cell lung cancer. J Clin Oncol. 2013; 31:4105-14.

109. Hirsch FR, Govindan R, Zvirbule Z, Braiteh F, Rittmeyer A, Belda-Iniesta C, Isla D, Cosgriff T, Boyer M, Ueda M, Phan S, Gandara DR. Efficacy and safety results from a phase II, placebo-controlled study of onartuzumab plus firstline platinum-doublet chemotherapy for advanced squamous cell non-small-cell lung cancer. Clin Lung Cancer. 2017; 18:43-49.

110. Wakelee HA, Gettinger S, Engelman J, Jänne PA, West H, Subramaniam DS, Leach J, Wax M, Yaron Y, Miles DR, Lara PN. A phase Ib/II study of cabozantinib (XL184) with or without erlotinib in patients with non-small cell lung cancer. Cancer Chemother Pharmacol. 2017; 79:923-932. https://doi.org/10.1007/s00280-017-3283-z.

111. Chen G, Noor A, Kronenberger P, Teugels E, Umelo IA, De Grève J. Synergistic effect of afatinib with su11274 in nonsmall cell lung cancer cells resistant to gefitinib or erlotinib. PLoS One. 2013; 8:e59708. https://doi.org/10.1371/journal. pone. 0059708 .

112. Puri N, Khramtsov A, Ahmed S, Nallasura V, Hetzel JT, Jagadeeswaran R, Karczmar G, Salgia R. A selective small molecule inhibitor of c-Met, PHA665752, inhibits tumorigenicity and angiogenesis in mouse lung cancer xenografts. Cancer Res. 2007; 67:3529-34.

113. Morris SW, Kirstein MN, Valentine MB, Dittmer KG, Shapiro DN, Saltman DL, Look AT. Fusion of a kinase gene, ALK, to a nucleolar protein gene, NPM, in nonHodgkin's lymphoma. Science. 1994; 263:1281-84.

114. Soda M, Choi YL, Enomoto M, Takada S, Yamashita Y, Ishikawa S, Fujiwara S, Watanabe H, Kurashina K, Hatanaka H, Bando M, Ohno S, Ishikawa Y, et al. Identification of the transforming EML4-ALK fusion gene in non-small-cell lung cancer. Nature. 2007; 448:561-66.

115. Gridelli C, Peters S, Sgambato A, Casaluce F, Adjei AA, Ciardiello F. ALK inhibitors in the treatment of advanced NSCLC. Cancer Treat Rev. 2014; 40:300-06.

116. Roskoski R Jr. Anaplastic lymphoma kinase (ALK): structure, oncogenic activation, and pharmacological inhibition. Pharmacol Res. 2013; 68:68-94.

117. Inamura K, Takeuchi K, Togashi Y, Hatano S, Ninomiya H, Motoi N, Mun MY, Sakao Y, Okumura S, Nakagawa K, Soda M, Choi YL, Mano H, Ishikawa Y. EML4-ALK lung cancers are characterized by rare other mutations, a TTF-1 cell lineage, an acinar histology, and young onset. Mod Pathol. 2009; 22:508-15.

118. Sasaki T, Rodig SJ, Chirieac LR, Jänne PA. The biology and treatment of EML4-ALK non-small cell lung cancer. Eur J Cancer. 2010; 46:1773-80.

119. Sasaki T, Koivunen J, Ogino A, Yanagita M, Nikiforow S, Zheng W, Lathan C, Marcoux JP, Du J, Okuda K, Capelletti M, Shimamura T, Ercan D, et al. A novel ALK secondary mutation and EGFR signaling cause resistance to ALK kinase inhibitors. Cancer Res. 2011; 71:6051-60.

120. Doebele RC, Pilling AB, Aisner DL, Kutateladze TG, Le AT, Weickhardt AJ, Kondo KL, Linderman DJ, Heasley LE, Franklin WA, Varella-Garcia M, Camidge DR. Mechanisms of resistance to crizotinib in patients with ALK gene rearranged non-small cell lung cancer. Clin Cancer Res. $2012 ; 18: 1472-82$. 
121. Khozin S, Blumenthal GM, Zhang L, Tang S, Brower M, Fox E, Helms W, Leong R, Song P, Pan Y, Liu Q, Zhao P, Zhao $\mathrm{H}$, et al. FDA approval: ceritinib for the treatment of metastatic anaplastic lymphoma kinase-positive non-small cell lung cancer. Clin Cancer Res. 2015; 21:2436-39.

122. Tani T, Yasuda H, Hamamoto J, Kuroda A, Arai D, Ishioka K, Ohgino K, Miyawaki M, Kawada I, Naoki K, Hayashi Y, Betsuyaku T, Soejima K. Activation of EGFR bypass signaling by TGFalpha overexpression induces acquired resistance to alectinib in ALK-translocated lung cancer cells. Mol Cancer Ther. 2016; 15:162-71.

123. Seto T, Kiura K, Nishio M, Nakagawa K, Maemondo M, Inoue A, Hida T, Yamamoto N, Yoshioka H, Harada M, Ohe Y, Nogami N, Takeuchi K, et al. CH5424802 (RO5424802) for patients with ALK-rearranged advanced non-small-cell lung cancer (AF-001JP study): a single-arm, open-label, phase 1-2 study. Lancet Oncol. 2013; 14:590-98.

124. Solomon BJ, Mok T, Kim DW, Wu YL, Nakagawa K, Mekhail T, Felip E, Cappuzzo F, Paolini J, Usari T, Iyer S, Reisman A, Wilner KD, et al, and PROFILE 1014 Investigators. First-line crizotinib versus chemotherapy in ALK-positive lung cancer. N Engl J Med. 2014; 371:2167-77.

125. Fontana D, Ceccon M, Gambacorti-Passerini C, Mologni L. Activity of second-generation ALK inhibitors against crizotinib-resistant mutants in an NPM-ALK model compared to EML4-ALK. Cancer Med. 2015; 4:953-65.

126. Shaw AT, Gandhi L, Gadgeel S, Riely GJ, Cetnar J, West H, Camidge DR, Socinski MA, Chiappori A, Mekhail T, Chao $\mathrm{BH}$, Borghaei H, Gold KA, et al, and study investigators. Alectinib in ALK-positive, crizotinib-resistant, non-smallcell lung cancer: a single-group, multicentre, phase 2 trial. Lancet Oncol. 2016; 17:234-42.

127. Tamura T, Kiura K, Seto T, Nakagawa K, Maemondo M, Inoue A, Hida T, Yoshioka H, Harada M, Ohe Y, Nogami N, Murakami H, Kuriki H, et al. Three-year follow-up of an alectinib phase i/ii study in alk-positive non-small-cell lung cancer: AF-001JP. J Clin Oncol. 2017; 35:1515-21.

128. Crinò L, Ahn MJ, De Marinis F, Groen HJ, Wakelee H, Hida T, Mok T, Spigel D, Felip E, Nishio M, Scagliotti G, Branle F, Emeremni C, et al. Multicenter phase II study of wholebody and intracranial activity with ceritinib in patients with alk-rearranged non-small-cell lung cancer previously treated with chemotherapy and crizotinib: results from ASCEND-2. J Clin Oncol. 2016; 34:2866-73.
129. Lim SM, Kim HR, Lee JS, Lee KH, Lee YG, Min YJ, Cho EK, Lee SS, Kim BS, Choi MY, Shim HS, Chung JH, La Choi Y, et al. Open-Label, Multicenter, phase II study of ceritinib in patients with non-small-cell lung cancer harboring ros1 rearrangement. J Clin Oncol. 2017; 35:2613-18.

130. Luk PP, Yu B, Ng CC, Mercorella B, Selinger C, Lum T, Kao S, O'Toole SA, Cooper WA. BRAF mutations in non-small cell lung cancer. Transl Lung Cancer Res. 2015; 4:142-48.

131. Davies H, Bignell GR, Cox C, Stephens P, Edkins S, Clegg S, Teague J, Woffendin H, Garnett MJ, Bottomley W, Davis N, Dicks E, Ewing R, et al. Mutations of the BRAF gene in human cancer. Nature. 2002; 417:949-54.

132. Platz A, Egyhazi S, Ringborg U, Hansson J. Human cutaneous melanoma; a review of NRAS and BRAF mutation frequencies in relation to histogenetic subclass and body site. Mol Oncol. 2008; 1:395-405.

133. Holderfield M, Deuker MM, McCormick F, McMahon M. Targeting RAF kinases for cancer therapy: BRAF-mutated melanoma and beyond. Nat Rev Cancer. 2014; 14:455-67.

134. Sánchez-Torres JM, Viteri S, Molina MA, Rosell R. BRAF mutant non-small cell lung cancer and treatment with BRAF inhibitors. Transl Lung Cancer Res. 2013; 2:244-50.

135. Noeparast A, Teugels E, Giron P, Verschelden G, De Brakeleer S, Decoster L, De Grève J. Non-V600 BRAF mutations recurrently found in lung cancer predict sensitivity to the combination of Trametinib and Dabrafenib. Oncotarget. 2016; 8:60094-108. https://doi.org/10.18632/ oncotarget. 11635 .

136. Planchard D, Kim TM, Mazieres J, Quoix E, Riely G, Barlesi F, Souquet PJ, Smit EF, Groen HJ, Kelly RJ, Cho BC, Socinski MA, Pandite L, et al. Dabrafenib in patients with BRAF(V600E)-positive advanced non-small-cell lung cancer: a single-arm, multicentre, open-label, phase 2 trial. Lancet Oncol. 2016; 17:642-50.

137. Planchard D, Smit EF, Groen HJ, Mazieres J, Besse B, Helland Å, Giannone V, D'Amelio AM Jr, Zhang P, Mookerjee B, Johnson BE. Dabrafenib plus trametinib in patients with previously untreated BRAFV600E-mutant metastatic non-small-cell lung cancer: an open-label, phase 2 trial. Lancet Oncol. 2017; 18:1307-16. 